\title{
High-Pressure Torsion of Non-Equilibrium Hydrogen Storage Materials: A Review
}

\author{
Ádám Révész * and Marcell Gajdics \\ Department of Materials Physics, Eötvös University, P.O.B. 32, H-1518 Budapest, Hungary; \\ gajdics.marcell@ttk.elte.hu \\ * Correspondence: reveszadam@ludens.elte.hu
}

check for

updates

Citation: Révész, Á.; Gajdics, M. High-Pressure Torsion of Non-Equilibrium Hydrogen Storage Materials: A Review. Energies 2021, 14, 819. https://doi.org/10.3390/ en14040819

Academic Editor: Antonio Barbucci

Received: 11 January 2021

Accepted: 1 February 2021

Published: 4 February 2021

Publisher's Note: MDPI stays neutral with regard to jurisdictional claims in published maps and institutional affiliations.

Copyright: (c) 2021 by the authors. Licensee MDPI, Basel, Switzerland. This article is an open access article distributed under the terms and conditions of the Creative Commons Attribution (CC BY) license (https:// creativecommons.org/licenses/by/ $4.0 /)$.

\begin{abstract}
As the most abundant element in the world, hydrogen is a promising energy carrier and has received continuously growing attention in the last couple of decades. At the very moment, hydrogen fuel is imagined as the part of a sustainable and eco-friendly energy system, the "hydrogen grand challenge". Among the large number of storage solutions, solid-state hydrogen storage is considered to be the safest and most efficient route for on-board applications via fuel cell devices. Notwithstanding the various advantages, storing hydrogen in a lightweight and compact form still presents a barrier towards the wide-spread commercialization of hydrogen technology. In this review paper we summarize the latest findings on solid-state storage solutions of different nonequilibrium systems which have been synthesized by mechanical routes based on severe plastic deformation. Among these deformation techniques, high-pressure torsion is proved to be a proficient method due to the extremely high applied shear strain that develops in bulk nanocrystalline and amorphous materials.
\end{abstract}

Keywords: high-pressure torsion; severe plastic deformation; hydrogen storage; Mg-based alloys; amorphous

\section{Introduction}

With the continuously increasing energy demand of the world, several problems associated with energy production have become more and more important $[1,2]$. Currently the vast majority of the energy we use is produced from non-renewable energy sources like coal, oil and natural gas [3,4]. The supply of these sources will inevitably deplete in the near future $[1,4,5]$ and their usage poses environmental issues, thus finding suitable alternatives is highly desirable. Unfortunately, a number of renewable energy sources (like wind or solar) are ill suited to deliver a continuous supply of energy which would be essential for (at least partly) replacing the existing (non-renewable) production methods. Renewable energy requires efficient storage, transportation and conversion into the energy form that is useful for the actual demand [6]. Consequently, energy storage technologies have to be developed to ensure the competitiveness and large-scale usability of renewable energy.

Hydrogen-based energy storage is one promising technology that uses hydrogen as an energy vector $[1,7]$. Its potential lies in some advantageous features of hydrogen like high energy density per mass unit (120-140 MJ/kg), high abundance, and the absence of harmful byproducts during its conversion in fuel cells $[1,2,4,8,9]$. Unfortunately, as hydrogen is a low-density gas at normal temperatures and pressures, its storage is difficult and this remains one of the major issues in the way of applications [10]. Apart from the traditional gas and liquid phase storage, hydrogen can be stored in the solid state, for example in the form of metal hydrides which offer significantly higher volumetric hydrogen densities $[2,4,10,11]$. Despite the extensive research in the past couple of decades, no material can simultaneously satisfy the performance requirements for hydrogen storage systems set up by the US Department of Energy (DOE) at present [12].

Nevertheless, notable progress has been made so far, for example, various catalysts, nanostructuring and different synthesis techniques have been developed and extensively 
used in order to improve the hydrogen storage properties of different solids [13-17]. In particular, creating nanostructured materials has received much attention in the past decades with the aim of increasing the active surface area and enhancing the diffusion of hydrogen in the material. High energy ball milling (HEBM) of powders has been frequently used to decrease the grain size to the nano-regime and to create different composites and alloys [14,16-19]. Notwithstanding the significant benefits, HEBM has some weaknesses in processing nanoscale hydrogen storage alloys, including the problem of scaling-up to the industrial level, exhaustive energy consumption, high production cost and potential fire risk. To address these issues, bulk processing techniques [20] based on severe plastic deformation (SPD) have recently been applied very intensively to obtain hydrogen storage materials with enhanced properties $[14,16,21,22]$. It was shown that the refinement of grain structure, the formation of high-angle grain boundaries and various lattice defects occurring during the SPD process have beneficial effects on the hydrogen sorption kinetics of the material $[14,21,22]$. The prospect of relatively simple and low cost manufacturing of bulk samples with better air resistance compared to powders makes these SPD techniques a promising supplement to the ball milling process. High-pressure torsion (HPT), the subject of the current review, is one of the severe plastic deformation methods which has been applied successfully to manufacture different hydrogen storage materials [23].

In this overview paper, we first describe the details of the HPT process, including models that estimate the temperature conditions in the highly deformed disk-shaped specimens (Section 2). As one of the most abundant solid-state hydrogen storage materials, Mg-based systems will be highlighted in Section 3, including the latest findings on nanocrystalline $\mathrm{Mg} / \mathrm{MgH}_{2}, \mathrm{Mg}-\mathrm{Ni}$, other Mg-based systems, and nanotube-catalyzed $\mathrm{Mg}$ processed by HEBM and HPT. In Section 4, several non-equilibrium Mg-(Ni,Cu)-(Y,Ce) glassy, partial amorphous, and crystalline alloys will be discussed with respect to their $\mathrm{H}$-storage performance. High-pressure torsion can significantly improve the sorption properties of other (mainly Ti-based) nanocrystalline systems as highlighted in Section 5. In the last part of the manuscript (Section 6), the improvement of H-production by HPT will be summarized.

\section{The High-Pressure Torsion Procedure}

Among the several SPD methods, HPT has received intensive attention in the last couple of decades due to the extremely high applied shear strain that can be achieved in bulky sample volumes [20]. As was highlighted by Edalati and Horita, the HPT technique was originally invented in 1935 by Bridgman [24].

During the HPT deformation technique, a cylindrical specimen (disk) is inserted between two stainless steel anvils and subjected to simultaneous uniaxial pressure of several GPa and concurrent torsional straining for $N$ number of whole turns $[25,26]$. The accumulated shear strain along the radius of the disk can be represented by

$$
\gamma=\frac{2 \pi N r}{L}
$$

where $r$ and $L$ are the distance from the rotation axis within the sample and the thickness of the disk, respectively [20,25]. Typical values achieved at the edge can be as high as $\gamma \sim 70-100$. At very high strains, the corresponding accumulated strain can be given as [24]

$$
\varepsilon \approx \ln \left(\frac{\theta r}{L}\right)=\ln \left(\frac{2 \pi N r}{L}\right)
$$

where $\theta$ is the angle of torsion.

In most cases, an HPT apparatus operates in constrained geometry without free surfaces, see the schematic illustration in Figure 1. In the case of a conventional HPTdevice, $r$ varies in the range of 3 to $10 \mathrm{~mm}$, while $L \sim 1 \mathrm{~mm}$, which means that the volume of an HPT-disk is about $100 \mathrm{~mm}^{3}$ and its mass is in the order of hundreds of milligrams. It is noted that a unique apparatus located at the Erich Schmid Institute (Leoben, Austria) enables a significant scaling-up, since $\mathrm{r}$ can exceed $5 \mathrm{~cm}$. It is noted that the highly 
inhomogeneous and anisotropic nature of the HPT deformation (see Equations (1) and (2)) was also supported by the finite element method [25].

Originally, this SPD method was applied to synthesize porosity-free bulk ultrafinegrained materials with submicron crystallite size [20,24,26-29], nevertheless, it has recently become a dominant technique to produce low-porosity metallic glass compacts from amorphous ribbon chips $[30,31]$ and reach large plastic strains in bulk metallic glass alloys (BMGs) [32-34]. In a novel paper, it was reviewed that HPT can induce significant plasticity in metallic glasses [35], while nanocrystallization of these alloys can also take place [36]. When HPT is applied to immiscible systems for extreme torsion numbers $(N=1500)$, new metastable phases can form by mixing the elements on the atomic scale [37]. These materials exhibit unpredictable hardness and tensile performance. Moreover, metastable phases and compounds beyond the equilibrium phase diagrams can also be designed [38].

It is an important issue whether the heat release during the heavy shear deformation results in any temperature rise in the specimen. It was recently found that the actual increase of the temperature measured directly by a thermocouple on pure metals is remarkably small [39], however, it is higher for harder materials and can reach $\Delta \mathrm{T}=80 \mathrm{~K}$, in accordance with finite element simulations [40]. For all materials, $\Delta \mathrm{T}$ is more pronounced with increasing the angular velocity of the apparatus. A free-volume-based simulation of high-pressure torsion of BMGs provides a simple relationship between the measured torque data and the temperature evolution and confirms a significant temperature rise in these materials as well [41]. A macroscopic thermoplastic model incorporating the numerical solution of the heat-conduction equation provides the time evolution and spatial distribution of temperature during the HPT procedure [42,43]. It was shown that small sample thickness and/or high deformation rate enables a drastic temperature rise $(\Delta \mathrm{T} \sim 300 \mathrm{~K})$, however, in other cases only a small increase is predicted in line with previous data.

A recent modification of the HPT method, continuous high-pressure torsion has significant merit, i.e., a saturated level of hardness and minimum grain size are reached in relatively short time [44]. It was demonstrated that a possible scaling up of HPT is feasible if the ring shape sample is subjected to the severe plastic deformation [45].

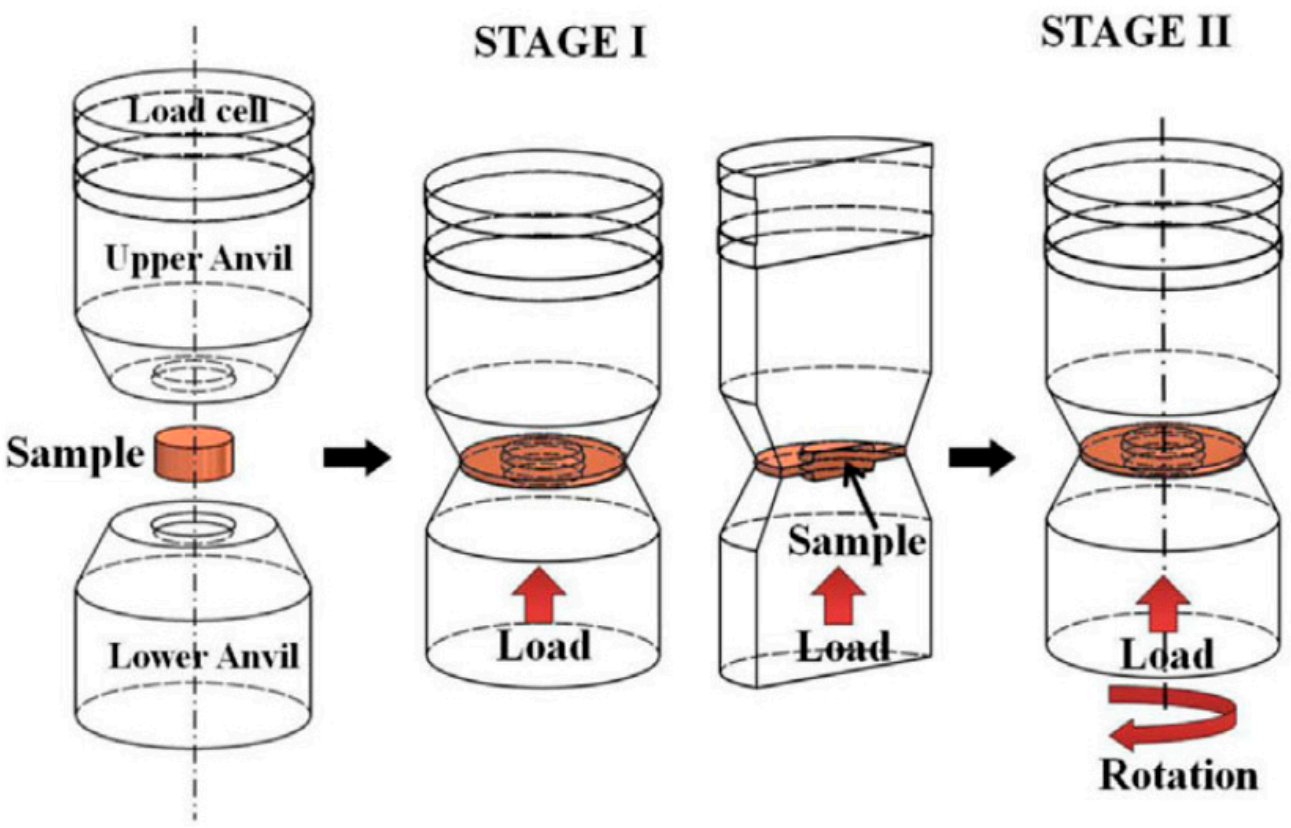

Figure 1. Schematic representation of the HPT apparatus with the uniaxial compression (I) and subsequent simultaneous compression and torsion (II) stages [46]. 


\section{Nanostructured Mg-Based Hydrogen Storage Systems}

\subsection{Elemental $\mathrm{Mg}$ and $\mathrm{MgH}_{2}$}

As was described in the Introduction part of this Review, solid-state hydrogen storage is still a significant technological challenge, nevertheless, numerous promising efforts have been occurred so far. Among metallic elements, magnesium attracts the highest interest in the field of solid-state hydrogen storage due to its very high theoretical gravimetric capacity (7.6 wt.\%). It was found that at temperatures and hydrogen partial pressures of practical interest of $\mathrm{H}$-storage, the $\alpha-\mathrm{MgH}_{2}$ tetragonal rutile structure is stable and stoichiometric (see Figure 2), in accordance with the small H-vacancy concentration [47].

Magnesium has several other advantages, i.e., it is lightweight, non-toxic, abundant and cheap $[8,15,48]$. On the other hand, the very high formation enthalpy $(\Delta \mathrm{H}=-78 \mathrm{~kJ} / \mathrm{mol})$ of the $\mathrm{MgH}_{2}$ phase (i.e., the high strength of the $\mathrm{Mg}-\mathrm{H}$ bonds), the high activation energy of $\mathrm{H}_{2}$ dissociation, and the sluggish sorption kinetics are the major drawbacks of on-board commercialization of $\mathrm{MgH}_{2}$ [15]. In order to overcome these difficulties, it is important to develop the kinetic and thermodynamic performance of Mg-based systems simultaneously. Until now, a large number of attempts have been targeted to deal with these issues, including nanostructuring by HEBM [49-51], which can significantly enhance the hydrogenation kinetics, particularly the diffusion of hydrogen due to the abundant grain boundaries and lattice defects $[16,52,53]$. Due to the different coordination number of the $\mathrm{Mg}$ and $\mathrm{H}$ atoms in the grain boundary region, the surface morphology usually can affect both the kinetic and thermodynamic performance of the Mg-nanoparticles [54]. The advantage of HEBM is not only manifested in rapid crystallite-size decrease, but the generation of metastable orthorhombic $\gamma-\mathrm{MgH}_{2}$ phase results in the decrease of the hydrogen sorption temperature [55].

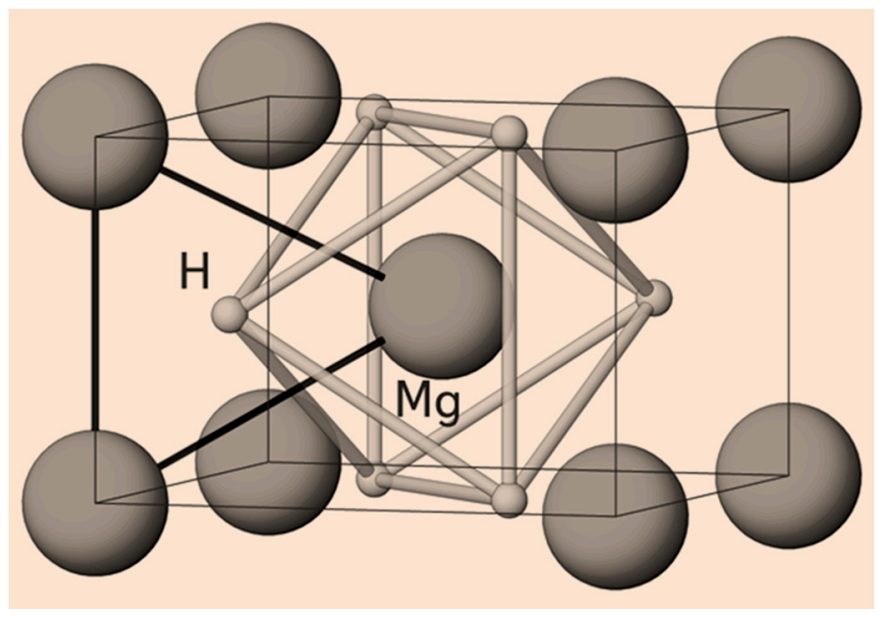

Figure 2. Tetragonal crystalline lattice of the rutile-type $\alpha-\mathrm{MgH}_{2}$ phase.

The microstructural characterization of consolidated $\mathrm{MgH}_{2}$ powders revealed that significant grain refinement of the hydride phase takes place during the HPT deformation with the average crystallite size in the range of $20 \mathrm{~nm}$ [56]. The severe shear deformation also provokes a strong (002) texture and the formation of the metastable $\gamma-\mathrm{MgH}_{2}$ phase. When HPT is applied for a different number of whole revolutions under $\mathrm{p}=6 \mathrm{GPa}$ to deform compacted $\alpha-\mathrm{MgH}_{2}$ micropowders, the material starts to transform into nanocrystalline high-pressure $\gamma$ phase [57]. As presented by the TEM micrographs in Figure 3, the shear strain leads to a significant crystallite size reduction after $N=15$ whole turns $(\sim 70 \mathrm{~nm})$, while the selected area diffraction (SAED) patterns and the corresponding fast Fourier transform (FFT) diffractograms confirm the gradual formation of the high pressure phase. This phase exhibits a lower hydrogen binding energy and accordingly a lower dehydrogenation temperature ( $\mathrm{T} \sim 610 \mathrm{~K})$. This study pointed out that varying the crystal structure is an efficient approach to destabilize the hydrides without compositional 
changes [57]. In a recent comparative research, $\mathrm{H}$-sorption behavior was analyzed on two different types of HPT consolidated Mg powder precursors. The results showed that the nature of the initial powders has a pronounced effect, i.e., the compacts prepared from ultrafine powder obeys faster absorption kinetics than the consolidated product obtained from micro-sized atomized powder [58]. Nevertheless, the latter sample can absorb more hydrogen and exhibits enhanced desorption.
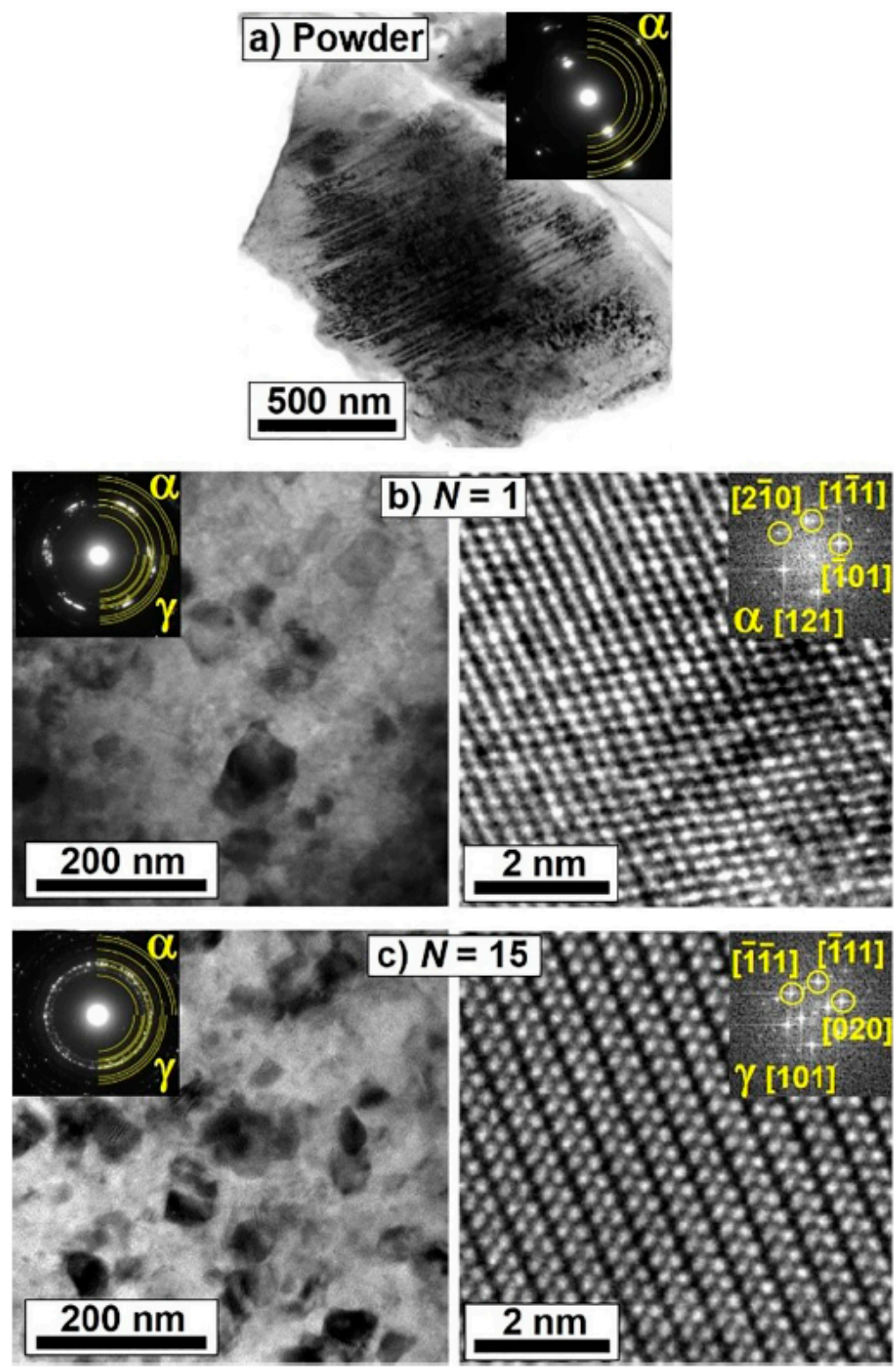

Figure 3. TEM images and corresponding SAED patterns (left) together with high-resolution lattice images and corresponding FFT diffractograms (right) for (a) tetragonal $\alpha-\mathrm{MgH}_{2}$ powder, disk processed by HPT under $\mathrm{p}=6 \mathrm{GPa}$ for $(\mathbf{b}) N=1$ and (c) $N=15$ whole turns [57].

When pure bulk Mg is torqued by HPT, a bimodal microstructure develops, including nanocrystals and large recrystallized grains with an average grain size of $\sim 1 \mu \mathrm{m}$. After $N=10$ torsion numbers, the hydrogenation improves significantly and the absorption rate is increased [59]. This phenomenon is mainly attributed to the presence of high-angle grain boundaries. The average dislocation density obtained from X-ray line profile analysis of commercial $\mathrm{Mg}$ disks processed by HPT reaches a very large value $\left(\rho=8 \cdot 10^{15} \mathrm{~m}^{-2}\right)$ at $N=10$, referring to the extreme intensity of shear deformation. The hydrogen storage 
capacity increases with increasing $N$ due to the formation of dislocations, which can act as hydrogen absorption sites [60]. The hydrogen storage capacity was found to be stable up to 200 hydrogenation/dehydrogenation cycles for the ZK60 Mg-alloy (Mg-5.8Zn$0.57 \mathrm{Zr}$, element concentration in wt.\%) processed by HPT [61]. At the same time, both the absorption and desorption curves can satisfactorily be fitted by the Johnson-Mehl-Avrami function with an exponent $\mathrm{n}=1$ for all investigated cycling numbers (see Figure 4 ), which can be attributed to the high density of hydride nuclei hindering each other to grow.
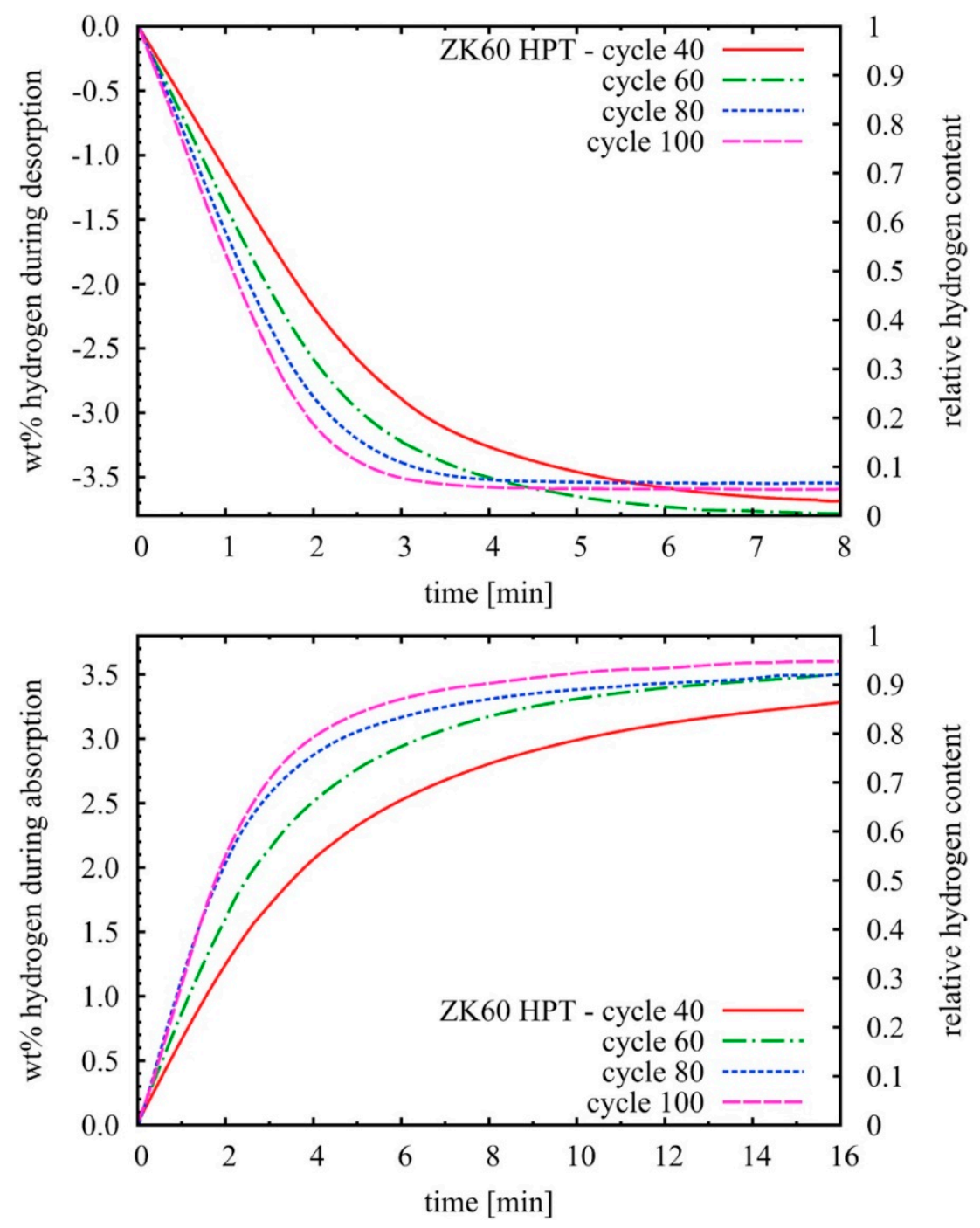

Figure 4. Dehydrogenation (top) and hydrogenation kinetic curves (bottom) obtained at $350{ }^{\circ} \mathrm{C}$, 10 bar absorption pressure, 0.001 bar desorption pressure of the HPT-deformed ZK60 alloy [61].

\subsection{Mg-Ni System}

Alloying Ni to Mg by HEBM results in an excellent combination of advantageous thermodynamics [62] and improved hydrogen sorption by accelerating the recombination/dissociation of hydrogen atoms at the grain boundaries [63,64]. Based on the binary $\mathrm{Mg}-\mathrm{Ni}$ phase diagram, the two elements are mutually insoluble [65], while two intermetallic line compounds, i.e., $\mathrm{Mg}_{2} \mathrm{Ni}$ and $\mathrm{MgNi}_{2}$ exist, nonetheless only $\mathrm{Mg}_{2} \mathrm{Ni}$ reacts with hydrogen with a $3.62 \mathrm{wt} . \%$ gravimetric capacity [66]. Moreover, a remarkable reduction of hydrogen desorption temperature was obtained when $\mathrm{MgH}_{2}$ was catalyzed by $\mathrm{Ni}[67,68]$. By varying HEBM parameters and the composition of the Mg-Ni powder blend, either a $\mathrm{Mg}+\mathrm{Ni} \rightarrow \mathrm{Mg}_{2} \mathrm{Ni}$ mechanochemical reaction [69-71] or (partial) solid state amorphization can take place [72]. 
In pioneering research carried out on the HPT deformation of the Mg-Ni system, it was demonstrated that the extreme shear deformation can reach such levels that it is capable to provoke hydrogen absorption in the otherwise non-absorbing $\mathrm{MgNi}_{2}$ phase [73]. In recent work, it was demonstrated that the maximum $\mathrm{H}$-absorption capacity of a $\mathrm{Mg}_{70} \mathrm{Ni}_{30}$ alloy is increased by $30-50 \%$ after HPT with respect to HEBM and can reach the theoretical value, due to the creation of new possible hydrogen absorption sites at the grain boundaries and near the vicinity of dislocations generated during the simultaneous compression and torsional straining [74]. Besides dislocations, other lattice defects, like stacking faults clearly improve the kinetics of $\mathrm{Mg}_{2} \mathrm{Ni}$ processed by HPT [75]. It was also suggested that a large fraction of cracks can act as pathways to transport the hydrogen from the surface of the HPT disk and activate the material with fast kinetics. A new processing route, i.e., HPT of ultrafine $\mathrm{Mg}+2 \mathrm{wt}$.\% Ni powder prepared by arc plasma evaporation significantly improves the $\mathrm{H}$-kinetics and results in a hydrogen uptake at $100{ }^{\circ} \mathrm{C}$ [76]. Interestingly, the co-deformation of $2 \mathrm{wt}$ \% Fe to $\mathrm{Mg}$ by HPT has a negligible effect on the H-storage performance of $\mathrm{Mg}$, probably because ultrafine Fe powder particles did not intermix with $\mathrm{Mg}$.

Partially hydrogenated and dehydrogenated states of a nanocrystalline $\mathrm{Mg}_{75} \mathrm{Ni}_{25}$ sample processed by HEBM and subsequent HPT technique revealed the formation of $\mathrm{Mg}_{2} \mathrm{NiH}_{0.3}$ hexagonal solid solution and the monoclinic $\mathrm{Mg}_{2} \mathrm{NiH}_{4}$ hydride phase during absorption [77]. The desorption induced changes in the relative amount of the two hydride phases indicated that the volumetric decrease of $\mathrm{Mg}_{2} \mathrm{NiH}_{4}$ and $\mathrm{Mg}_{2} \mathrm{NiH}_{0.3}$ is not simultaneous, i.e., at the initial stage of dehydrogenation, the decomposition of $\mathrm{Mg}_{2} \mathrm{NiH}_{4}$ is favored, while subsequently, the $\mathrm{Mg}_{2} \mathrm{NiH}_{0.3} \rightarrow \mathrm{Mg}_{2} \mathrm{Ni}+0.3 \mathrm{H}_{2}$ reaction becomes more dominant (see Figure 5). It was also shown that the combination of HEBM and HPT is an effective deformation route to preserve the nanostructure of the alloy during the entire hydrogenation-dehydrogenation process. Complimentary high-pressure calorimetry confirmed a two-step sorption sequence both upon heating and cooling [78]. At the early stage of decomposition, the desorption of $\mathrm{Mg}_{2} \mathrm{NiH}_{4}$ occurs which is followed by the dehydrogenation of $\mathrm{Mg}_{2} \mathrm{NiH}_{0.3}$ solid solution. The enthalpy of hydrogenation/dehydrogenation reactions determined from the corresponding van't Hoff plots suggests that HPT promotes the destabilization of the metal-hydrogen bonds.

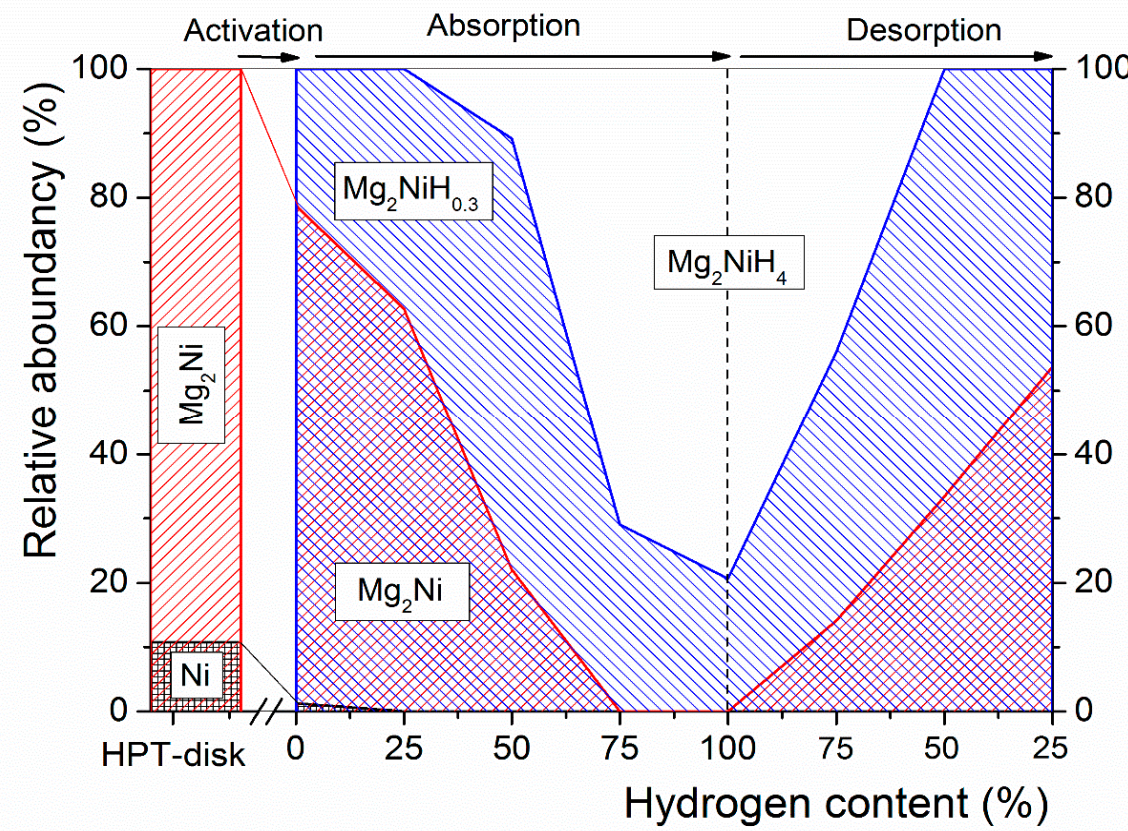

Figure 5. Evolution of phase composition during hydrogenation and dehydrogenation of the $\mathrm{Mg}-\mathrm{Ni}$ HPT-disk [77]. 


\subsection{Formation of New Hydrogen Storage Phases by HPT in Other Mg-Based Systems}

The large plastic strain accompanying the high-pressure torsion procedure not only results in the reduction of the grain size and introduction of lattice defects but also new stable and even metastable phases can form in certain systems [37]. Accordingly, $\mathrm{Mg}_{2} \mathrm{Sn}$ and $\mathrm{Mg}_{2} \mathrm{Ni}$ intermetallics have formed after $\mathrm{N}=100$ rotations in $\mathrm{Mg}-\mathrm{V}-\mathrm{Sn}$ and $\mathrm{Mg}-\mathrm{V}-\mathrm{Ni}$ systems, respectively. Further increasing the number of revolutions results in the evolution of metastable phases in the Mg-V-Pd [37] alloy. It is noted that the corresponding binary systems have negative ( $\mathrm{Mg}-\mathrm{Pd}[79]$ and $\mathrm{Pd}-\mathrm{V})$ and positive mixing enthalpies $(\mathrm{Mg}-\mathrm{V}$ [37]) as well. It was also revealed that metastable phases can develop even in immiscible systems with positive heat of mixing such as $\mathrm{Mg}$-Ti [80] and $\mathrm{Mg}-\mathrm{Zr}$ [81].The ultra-severe plastic deformation can extend the solubility of the minor components, thus new hydrogen storing materials can be manufactured. For example, in the $\mathrm{Mg}-\mathrm{Zr}$ system $N=1000$ revolutions results in significant mixing of $\mathrm{Mg}$ and $\mathrm{Zr}$ (see Figure 6). Mutual dissolution of elements in the $\mathrm{Mg}-\mathrm{Ti}$ [81] and $\mathrm{Mg}-\mathrm{Zr}$ [79] systems were observed by scanning electron microscopy, whilst the formation of BCC, FCC and HCP Mg-Ti [81] and HCP Mg-Zr phases [79] were confirmed by X-ray diffraction. Furthermore, during shear straining of $\mathrm{MgH}_{2}-\mathrm{TiH}_{2}$ mixture metastable ternary Mg-Ti-H hydride phase develops [82].
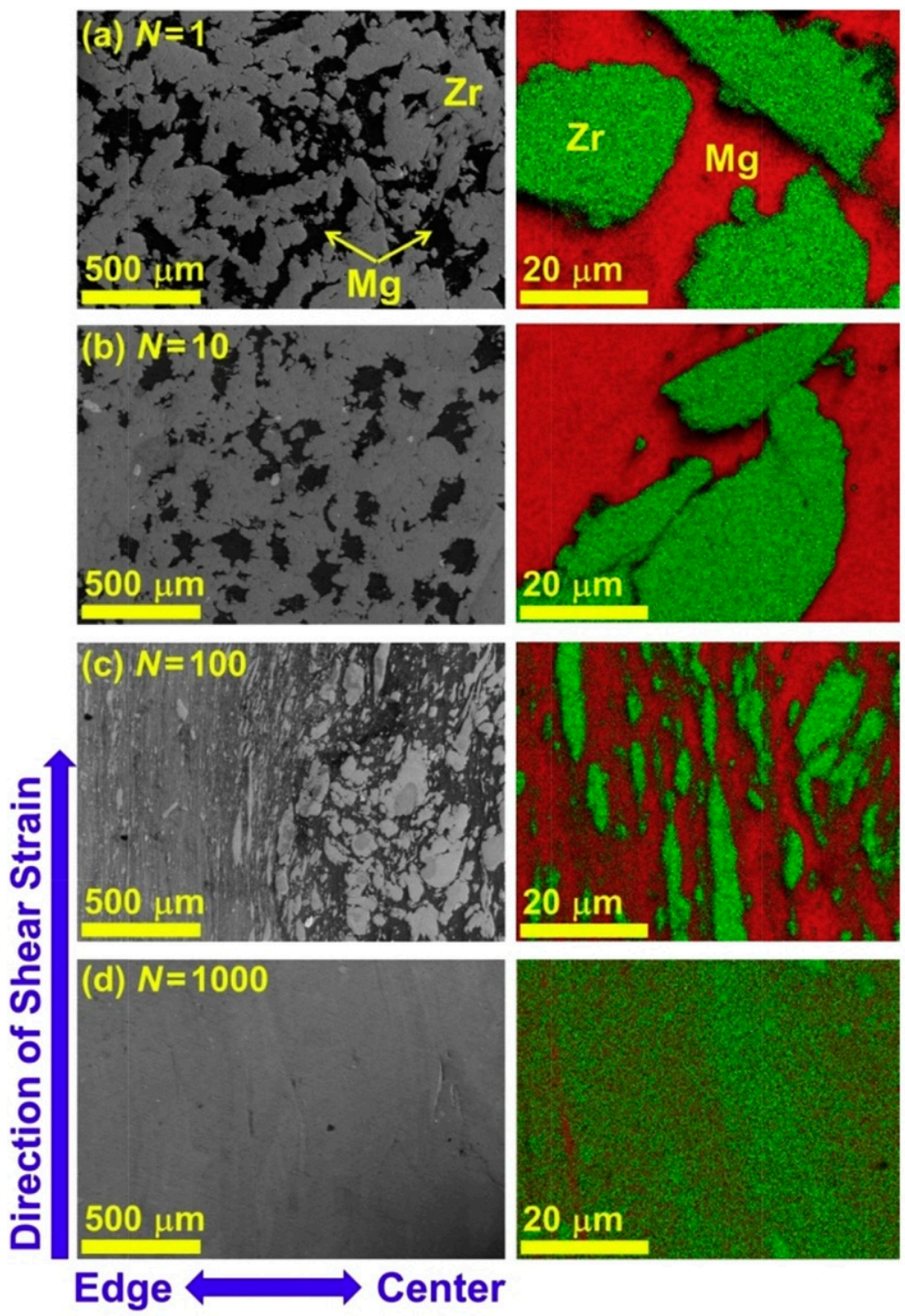

Edge

Figure 6. Scanning electron micrographs and EDS elemental mappings of the Mg-Zr alloy processed by HPT for different number of revolutions [81]. 
A first principle calculation to design Mg-based alloys with low binding energy was recently reported [83]. Accordingly, a $\mathrm{Mg}_{4} \mathrm{NiPd}$ alloy of $\mathrm{CsCl}$-type BCC structure has been fabricated by HPT through $N=1500$ revolutions. This alloy is highly metastable, preserves its structure up to $440 \mathrm{~K}$ and possesses an extremely low (close to zero) hydrogen binding energy which enables reversible absorption and desorption of hydrogen at room temperature. At the same time, the reversible storage performance remains stable after five sorption cycles. This pioneering work of Edalati et al. demonstrated first that tuning the dehydrogenation temperature of $\mathrm{Mg}$-based alloys to room temperature is possible by applying binding energy principles. As a continuation of this concept, a metastable FCC structure was also generated by HPT in the Mg-Hf binary system, however, attempts to produce magnesium-hafnium hydrides have been unsuccessful so far [84].

A recent paper has demonstrated that high-pressure torsion can be utilized for the synthesis of high-entropy materials for hydrogen storage [85]. MgVCr BCC and MgVTiCrFe high-entropy alloys were successfully synthesized via the combination of HEBM and HPT. The structure of the $\mathrm{MgVTiCrFe}$ product exhibits nanocrystalline and amorphous character. Nevertheless, it was shown that the $\mathrm{MgVCr}$ possesses higher hydrogen storage capacity, better kinetics and phase stability compared to the $\mathrm{MgVTiCrFe}$ alloy.

\subsection{Nanocrystalline Mg Catalyzed by Nanotube Additives}

Several recent researches have been dedicated to the addition of carbon nanotubes (CNT) to nanocrystalline hydrogen storage materials to improve the kinetic behavior during absorption and desorption. It was demonstrated that only a few wt.\% of CNT results in greatly enhanced kinetics of sorption reactions in $\mathrm{Mg}-\mathrm{Ni}$ alloys [86,87]. CNT catalyzed $\mathrm{Mg}$ was able to absorb approximately 1.5 times more hydrogen than its uncatalyzed counterpart during the first couple of minutes of hydrogenation [88]. Based on these works, it is believed that the role of the carbon nanotubes in absorption/desorption reactions is to provide fast diffusion channels for the hydrogen atoms through a surface passivation layer into the bulk material $[86,89]$. Apart from the kinetic improvements, it was also proved that $\mathrm{CNT}$ addition is an efficient way to improve the long-term cycling stability of $\mathrm{MgH}_{2}[90,91]$. It was indicated that a synergetic effect may emerge between CNTs and other types of catalysts, such as $\mathrm{Co}$ [92], $\mathrm{TiF}_{3}$ [90], or $\mathrm{Nb}_{2} \mathrm{O}_{5}$ [93].

In a recent research, the influence of the different deformation routes on the microstructural evolution and hydrogen storage behavior of nanocrystalline $\mathrm{Mg}$ catalyzed by $\mathrm{Nb}_{2} \mathrm{O}_{5}$ and/or CNT have been demonstrated [94]. The systematic kinetic analysis of the hydrogen sorption of $\mathrm{Mg}$ catalyzed by these additives is presented in Figure 7 [94]. As seen, the addition of $\mathrm{Nb}_{2} \mathrm{O}_{5}$ is important to achieve appropriate hydrogen sorption properties, however, it is also evident that the combination of the HEBM+HPT process or the addition of CNT catalyst can further improve the desorption kinetics of nanocrystalline $\mathrm{Mg}$. The observed improvement was appropriated to the (002) texture (which is preserved during cycling) developed through the HPT procedure. Post-cycling XRD experiments demonstrated that the HPT processing or the CNT additive prevents excessive grain growth during cycling. A high resolution TEM image of the Mg-NbO-CNT disks confirms that the main portion of the CNTs is preserved during the extreme plastic deformation of HEBM, subsequent HPT, and hydrogenation/dehydrogenation cycling (see Figure 7) [94]. It was also shown that HEBM parameters also significantly affect the sorption performance of the final $\mathrm{Mg}-\mathrm{NbO}-\mathrm{CNT}$ HPT samples [95]. 

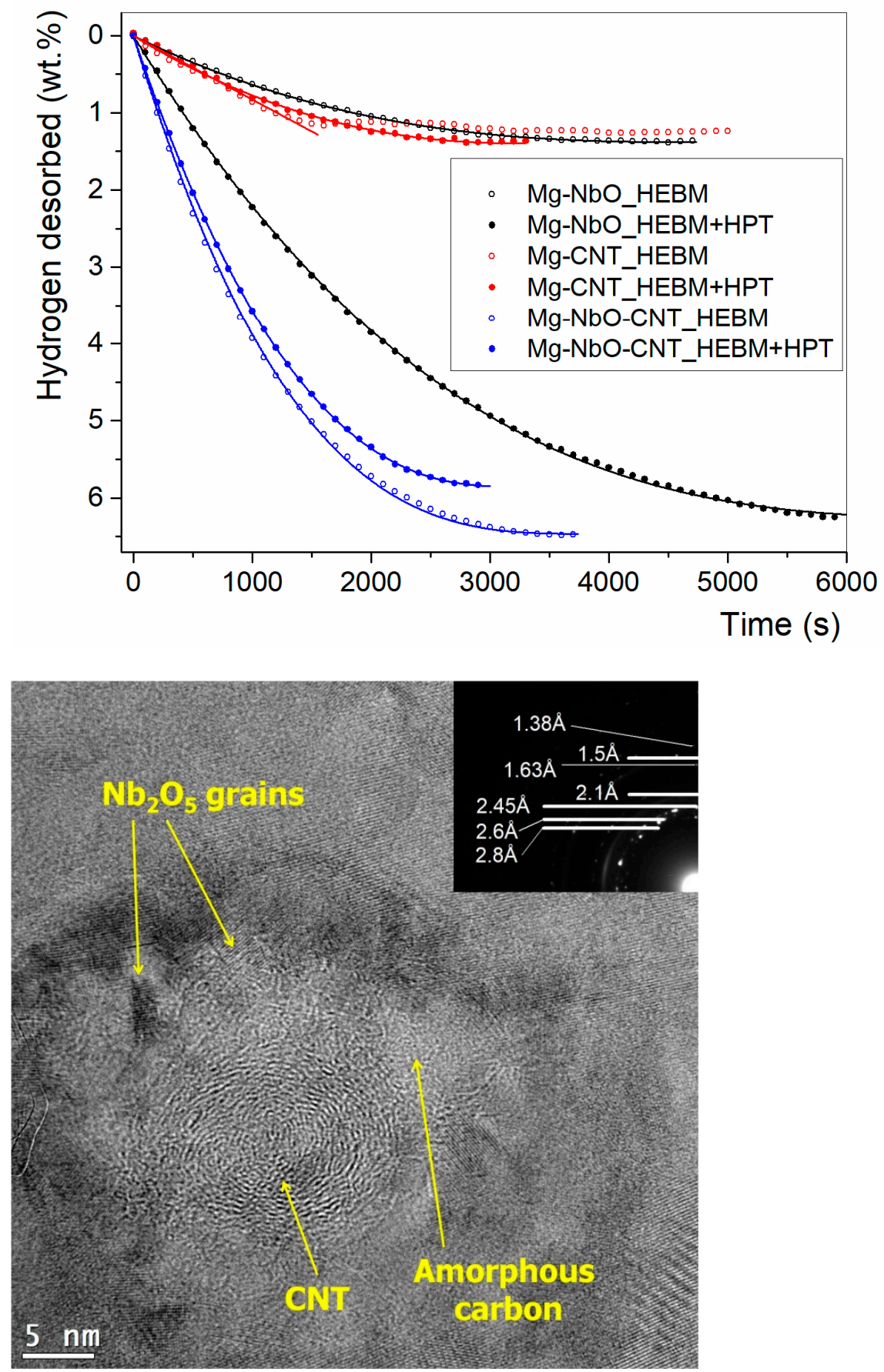

Figure 7. Measured desorption kinetic curves obtained at $573 \mathrm{~K}$ and $p=1 \mathrm{kPa}$ of the as-milled powder samples and HPT-disks, with fitted model functions (top). HR-TEM image of the cycled Mg-NbO-CNT_HPT disk, the inset shows a typical SAED pattern (bottom) [94].

In a very recent paper, we have shown that the combined catalytic effect of metal-oxide particles and CNTs can be replaced by applying only titanate nanotubes (TN) [96], note that this research is still in progress. In this preliminary work, the HEBM+HPT deformation route was applied on nanocrystalline $\mathrm{Mg}$ powders catalyzed by TN. As was shown the $\mathrm{HPT}$ processing results in the decrease of the average crystallite size of HEBM Mg powders and at the same time a strong texture was also developed. In addition, the processing route considerably influences the $\mathrm{H}$-sorption kinetics, i.e., the hydrogenation performance (capacity and kinetics) of the composite produced for longer co-milling of TN together with $\mathrm{Mg}$ significantly exceeds the sorption properties of the specimen when $\mathrm{Mg}$ was pre-milled 
and then milled together with TN for a short time. This observation can be attributed to the different morphology of the additives (better dispersed and partially damaged TN sections) and less to the microstructural parameters of the nanocrystalline $\mathrm{Mg}$ phase.

\section{Hydrogen Storage in the Non-Equilibrium Mg-(Ni-Cu)-(Y-Ce) System}

Besides severe plastic deformation techniques (HEBM and HPT), alternative methods via rapid quenching, such as melt spinning and copper mould casting are also available to produce H-storage magnesium and magnesium-nickel based alloys. The as-quenched non-equilibrium alloy can either contain several fully crystalline phases [97-99], a supersaturated solid solution [100], partial amorphous structure [101], or monolithic amorphous glassy phase [102-104].

It was reported that the $\mathrm{Mg}-\mathrm{Ni}-\mathrm{Ce}$ system exhibits a hydrogen induced glass-to-glass transition with a storage capacity of $5 \mathrm{wt} . \% \mathrm{H}_{2}$, which value is significantly higher than it was obtained for the crystalline alloy with similar composition, owing to the disordered atomic structure and free volume of the glass [105]. The hydriding/dehydriding performance of an as-quenched $\mathrm{Mg}-\mathrm{Ni}-\mathrm{Y}$ alloy synthesized by rapid-quenching is comparable to that of nanocrystalline $\mathrm{Mg}_{2} \mathrm{Ni}$ obtained by ball-milling [106]. It was also found that the amorphous $\mathrm{Mg}_{87} \mathrm{Ni}_{12} \mathrm{Y}_{1}$ alloy exhibits faster hydrogenation kinetics than the partially or fully crystallized alloys, due to the faster hydrogen diffusion in the amorphous phase, nevertheless, the H-capacity is practically independent of the atomic structure [106]. Melt-spun magnesium rich partially crystalline $\mathrm{Mg}_{80} \mathrm{Ni}_{10} \mathrm{Y}_{10}$ alloy possesses excellent hydrogenation/dehydrogenation properties after several thermal activation cycles [107], while supersaturated $\mathrm{Mg}_{12} \mathrm{YNi}$ solid solution shows fast kinetics of hydrogen absorption/desorption due to the catalytic effect of $\mathrm{Mg}_{2} \mathrm{Ni}$ and $\mathrm{Y}$ [100]. In the rapidly quenched $\mathrm{Mg}-\mathrm{Ni}-\mathrm{Mm}(\mathrm{Mm}=\mathrm{Ce}, \mathrm{La})$ system the precipitation of the $\mathrm{Mg}_{12} \mathrm{Mm}$ intermetallic phase preferentially occurs at the Mg grain boundaries providing pathways for enhanced hydrogen diffusion [108]. In order to further improve the sorption behaviour of as-spun nanocrystalline Mg-Ni-based alloys, Ni was partially substituted by Cu [99] or Co [109]. As was demonstrated, the applied melt spinning rate has a significant influence on the sorption properties of these alloys $[108,110]$. The enhanced H-storage performance of the amorphous ternary $\mathrm{Mg}_{86} \mathrm{~N}_{4} \mathrm{Y}_{10}$ glass can be attributed to the cracking and pulverization of the alloy pieces when a $\mathrm{MgH}_{2}$ matrix with finely dispersed $\mathrm{MgNiH}_{4}$ and $\mathrm{YH}_{3}$ grains evolve during the absorption process [111]. Hydrogenation of a rapidly quenched $\mathrm{Mg}-\mathrm{Ni}-\mathrm{Mm}$ alloy resulted in the formation of a metastable cubic $\mathrm{Mg}_{2} \mathrm{NiH}_{4}$ phase and the disappearance of the usual monolithic counterpart. This tendency becomes more pronounced with increasing the spinning velocity, in accordance with the increased mechanical stresses developed in the ribbon pieces [112]. A complex transformation behaviour during hydrogen absorption/desorption was explored by in-situ X-ray synchrotron radiation of the Mg-Ni-La system, including a previously non-reported early stage formation of a $\mathrm{La}_{2} \mathrm{Mg}_{17} \mathrm{H}_{\sim 1.0}$ solid solution [113]. Detailed thermal characterization of a $\mathrm{Mg}_{54} \mathrm{Cu}_{28} \mathrm{Ag}_{7} \mathrm{Y}_{11}$ BMG revealed that this composition has an excellent glass forming ability [114]. High pressure hydrogen-sorption experiments pointed out that the as-cast fully amorphous alloy exhibits the largest enthalpy of desorption, compared to the partially and fully crystallized states having similar concentrations. Since the fully crystallized sample does not desorb hydrogen at all, it can be assumed that the disordered local atomic structure of the glass is accountant for the hydrogen release [114].

The hydrogenation performance of BMGs and other glassy alloys can significantly be improved when the material is subjected to severe plastic deformation by HPT. A novel $\mathrm{Mg}_{65} \mathrm{Ni}_{20} \mathrm{Cu}_{5} \mathrm{Ce}_{10}$ nanoglass synthesized by rapid-quenching and subsequent torsional straining exhibits a reduced hydrogenation temperature and improved H-sorption kinetics [115]. These enhancements can be attributed to the interfaces between the nanoglass regions that are developed during the HPT-process which can serve as abundant pathways for fast hydrogenation. 
High magnification SEM-FIB images taken from the inner surface of the ion-milled notches of the $\mathrm{Mg}_{65} \mathrm{Ni}_{20} \mathrm{Cu}_{5} \mathrm{Y}_{10}$ fully amorphous alloy deformed by HPT are presented in Figure 8 [116]. The photograph corresponding to the central region of the disk (where the deformation is the smallest, see Equation (1)) presents a couple of larger crystalline regions (typical diameter $\sim 1 \mu \mathrm{m}$ ) embedded in the contrastless amorphous matrix (Figure 8a). EDX analysis of this area revealed that the composition of these blocks is very close to $\mathrm{Mg}_{2} \mathrm{Ni}$. Contrarily, the most strained periphery regions show a very different morphology characterized by plenty of crystals ranging from 30 to $500 \mathrm{~nm}$ (Figure 8b).

High-pressure calorimetric measurements corresponding to the reference $\mathrm{Mg}_{65} \mathrm{Ni}_{20} \mathrm{Cu}_{5} \mathrm{Y}_{10}$ crystalline alloy, the fully amorphous as-quenched ribbon and the HPT-disk processed for $N=2$ whole revolutions are depicted in Figure 9 [117]. A clear exothermic peak with a maximum at $\mathrm{T}_{\mathrm{abs}}=537 \mathrm{~K}$ characterizes the thermogram of the crystallized sample containing multiple compound phases $\left(\mathrm{Mg}_{2} \mathrm{Ni}, \mathrm{Mg}_{6} \mathrm{Ni}, \mathrm{Mg}_{2} \mathrm{Cu}, \mathrm{Mg}, \mathrm{Ni}, \mathrm{Mg}_{24} \mathrm{Y}_{5}\right)$. This exothermic heat contribution can be assigned to the formation of a hydrogen solid solution mainly into the $\mathrm{Mg}_{2} \mathrm{Ni}$ phase. A broader $\mathrm{H}$-absorption peak with comparable enthalpy release characterizes the measurement of the fully amorphous structure, however, this transformation occurs at $\mathrm{T}_{\mathrm{abs}} \sim 390 \mathrm{~K}$, i.e., well below the glass transition temperature. The observed decrease of $\mathrm{T}_{\mathrm{abs}}$ can be correlated with the specific structural features of the amorphous phase, such as lower excess free volume and atomic density [118], which can result in faster diffusion of $\mathrm{H}$-atoms and shorter diffusion distances. When the as-quenched amorphous material is subjected to intensive straining by HPT, the hydrogenation takes place in the 310-420 K temperature range, similarly to the original alloy. At the same time, the enthalpy of hydride formation increases substantially, which is in line with the nucleation of deformation induced $\mathrm{Mg}_{2} \mathrm{Ni}$ crystals (see Figure 8), indicating that severe plastic deformation by HPT can provide additional hydrogen-sites and increase the storage performance of the material. This phenomenon is more pronounced for the most deformed (perimeter) region of the disk.
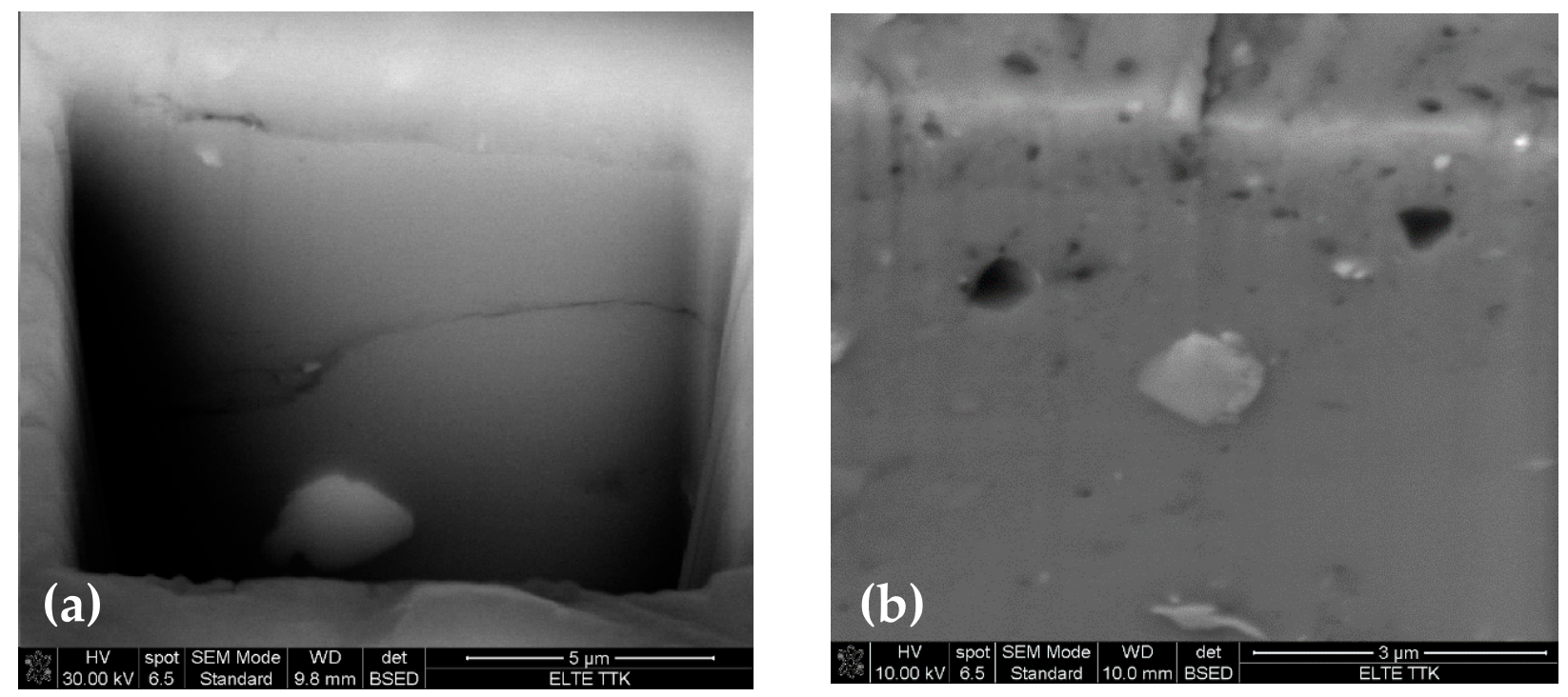

Figure 8. SEM-FIB images taken from the inner surface of the ion-milled notches corresponding to (a) central and (b) perimeter region of a $\mathrm{Mg}_{65} \mathrm{Ni}_{20} \mathrm{Cu}_{5} \mathrm{Y}_{10}$ amorphous HTP-disk [116]. 


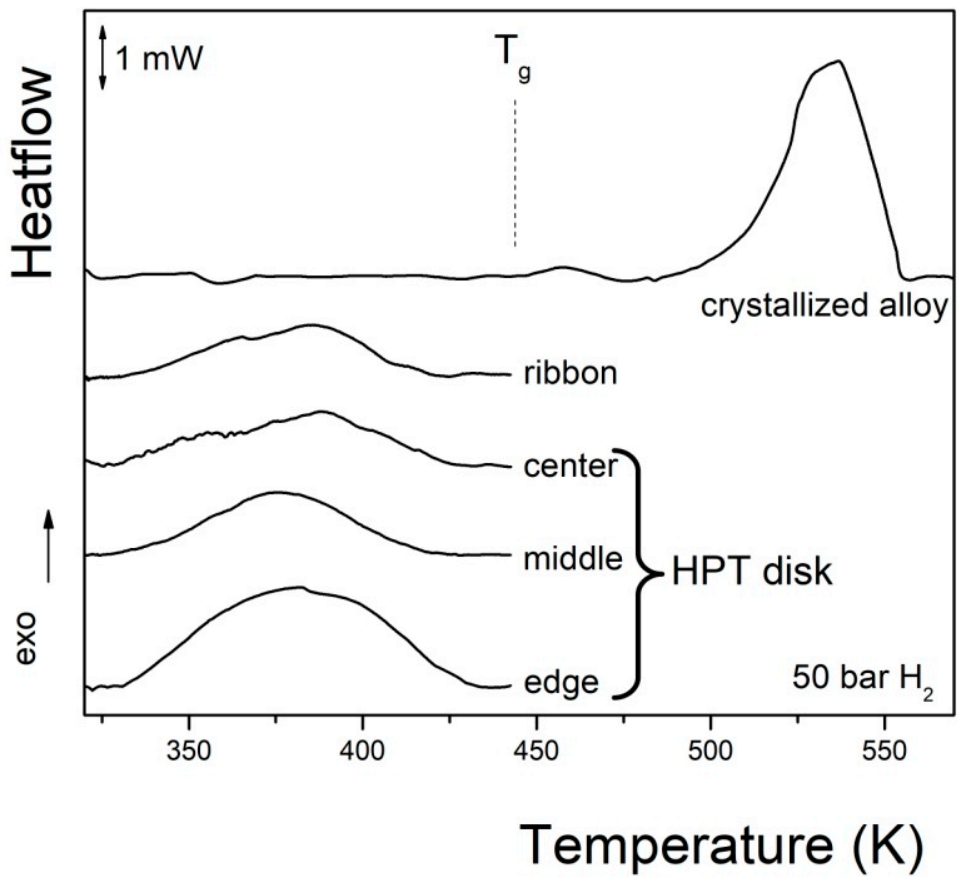

Figure 9. High-pressure DSC measurements on the reference $\mathrm{Mg}_{65} \mathrm{Ni}_{20} \mathrm{Cu}_{5} \mathrm{Y}_{10}$ crystalline sample, the fully amorphous ribbon, and different deformation states of the HPT-disk [117].

\section{Non-Magnesium-Based Materials}

TiFe intermetallic alloy is a potential candidate for hydrogen storage in stationary applications mostly due to its high volumetric capacity, low (de)hydrogenation temperature, reversibility and relatively low price $[119,120]$. Unfortunately, surface oxidation is a severe problem of this material which practically prevents the absorption of hydrogen. Hence an activation procedure is necessary which normally requires exposure to hydrogen (several MPa) at high temperature ( 673 K) [119,121]. It was also shown that the already activated TiFe easily deactivates if exposed to air [119]. Recently, the possibility of other activation routes was investigated using severe plastic deformation methods. Mechanical activation of TiFe via HPT [120], groove rolling [122], forging [123] and ball milling [124] were presented. Significant improvement in the room temperature hydrogen absorption was observed after HPT processing [120,122]. The material was capable to absorb $1.7 \mathrm{wt} . \%$ of hydrogen without any high temperature activation procedure (see Figure 10). It was also shown that the sample deformed by high-pressure torsion was able to absorb hydrogen even after several hundred days of storage in air, thus HPT not only activates TiFe but also prevents its deactivation upon air exposure [121]. Since the torsion process generates large number of grain boundaries, lattice defects and also cracks in the material, the atomic diffusion considerably enhances. These microstructural features act as pathways to hydrogen atoms through the surface oxide layer $[120,122]$. The refined structure is also responsible for keeping the sample activated upon contact with oxygen and permeable to hydrogen [121]. 


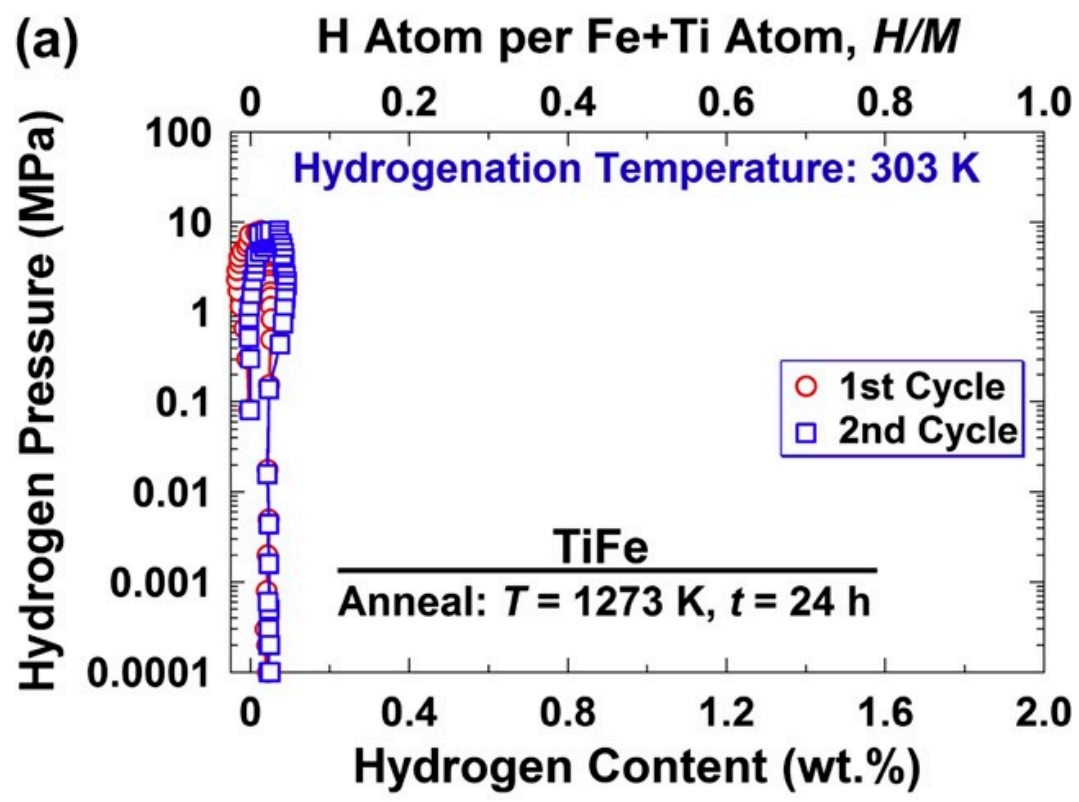

(b)

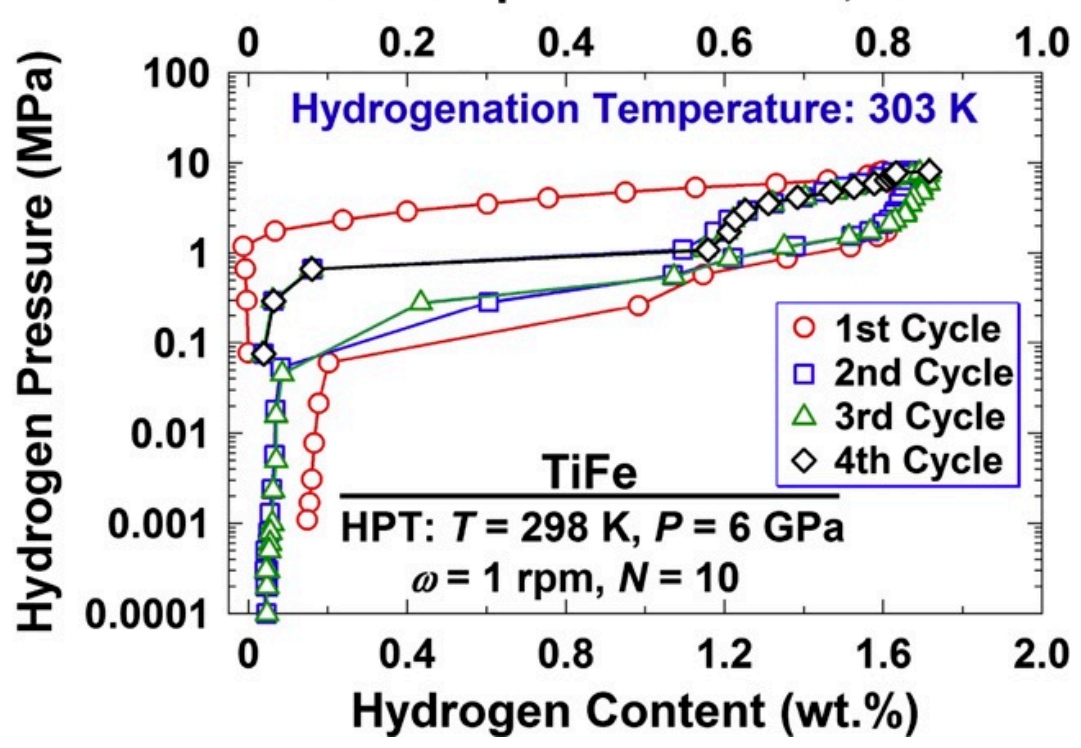

Figure 10. Pressure-composition isotherms of samples processed by (a) annealing under argon and (b) high-pressure torsion in the air [120].

The importance of the grain size and consequently the fraction of grain boundaries were demonstrated in ref. [122], where it was shown that the TiFe sample processed by HPT containing nanograins possessed better sorption capability than the groove rolled one with a mixture of micrometer sized and submicrometer sized grains [122]. It was also pointed out that after HPT processing Fe-rich islands form on the surface of the sample, according to the authors these may act as catalysts for hydrogen dissociation (see Figure 11) [121]. Another investigation on Ti-Fe-Mn intermetallics processed by HPT was demonstrated that the severe shear deformation not only creates lattice defects and grain boundaries but partial amorphization occurs as well. The amorphous regions can serve as channels for fast hydrogen diffusion, thus the heterogeneous microstructure consisting nanograins and amorphous areas is believed to be the reason for the observed fast hydrogenation [125]. 
In addition to the improvements of hydrogen sorption properties of TiFe by HPT, a very recent paper has demonstrated that TiFe alloy can even be produced via HPT from Ti and Fe powders [126].

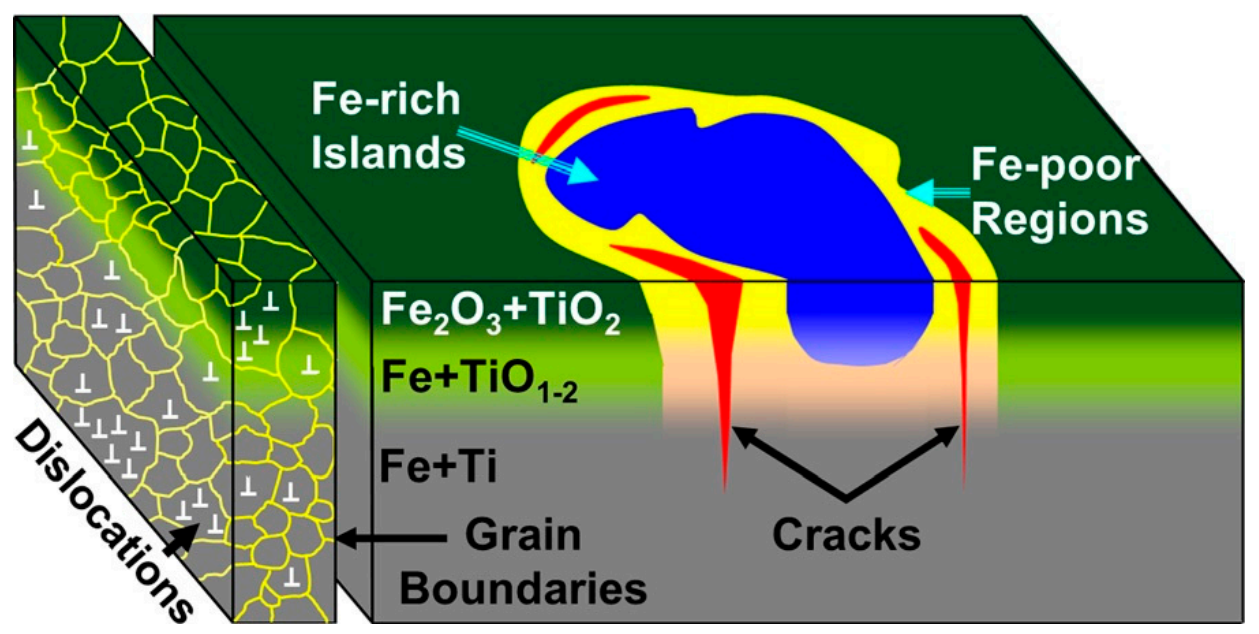

Figure 11. Schematic illustration of the most important microstructural features (i.e., cracks, grain boundaries, dislocations and Fe-rich islands) enhancing the activation of TiFe alloy [121].

Another interesting Ti-based hydrogen storing system is the Ti-V alloy, which is able to reversibly store $2 \mathrm{wt}$ \% of hydrogen at room temperature $[127,128]$. Similar to TiFe, $\mathrm{Ti}$-V-based alloys are also prone to surface passivation, thus an activation procedure is necessary for the first hydrogenation cycle. Additionally, they present slow hydrogen sorption kinetics [127]. Ti-V alloy was successfully synthesized at room temperature using a high-pressure torsion apparatus by Edalati and coworkers [127]. Hydrogen absorption at room temperature was observed without any high-temperature activation process. It was pointed out that a large amount of lattice defects (mainly edge dislocations) and grain boundaries not only accelerate the hydrogen diffusion but also enhance the nucleation and growth of the hydride phase. Surprisingly, the high density of lattice defects can also have a negative effect on the hydrogen desorption process, as was explored in the ternary Ti-V-Cr system [128,129]. Different microstructure (gradient structure) generated by ultrasonic surface mechanical attrition treatment has proved to be more suitable for activating and at the same time preserving the reversibility of Ti-V-Cr alloys [128,129].

The importance of HPT-created microstructure, particularly grain boundaries, was demonstrated in the case of pure $\mathrm{Pd}$ [130]. Hydrogen permeation tests have shown that the diffusion of hydrogen becomes faster (enhancement of the diffusion coefficient by $25 \%$ ) after the torsional deformation, mostly at lower temperatures (below $473 \mathrm{~K}$ ). The observed improvement was associated with the increment of the fraction of grain boundaries which act as diffusion paths for hydrogen. It was also revealed that the high-angle grain boundaries with random character (which are present in large number in the HPT-processed Pd) are the most important feature in accelerating the hydrogen diffusion as grain boundaries with lower energy may act as trapping sites [131]. Krystian et al. [132] have presented evidence of the formation of superabundant vacancies and vacancy-hydrogen clusters in Pd-H system after high-pressure torsion. The investigation indicated that these vacancy-hydrogen clusters (as obstacles for dislocations) may increase the stability of the microstructure of the material. Hongo et al. [133] have investigated the effect of hydrogen on the mechanical behavior of Pd processed by HPT. The authors have reported hydrogen-induced softening and plasticity in the ultrafine-grained sample as a result of hydrogen-enhanced localized plasticity in contrary to the coarse-grained reference sample in which hydrogen-induced embrittlement and hardening have occurred. 


\section{Improvement of Hydrogen Production by HPT}

Recently it was shown that the high-pressure torsion procedure can be used not only to enhance the hydrogen storage properties of materials but can also improve the hydrogen generation behavior of Al-based alloys and $\mathrm{TiO}_{2}$ as well. In Al-Sn and Al-Bi systems, the severe shear strain results in refined microstructure and increased density of $\mathrm{Al}-\mathrm{Sn}$ and $\mathrm{Al}-\mathrm{Bi}$ interfaces, respectively, which facilitate the hydrolysis reaction of $\mathrm{Al}$ in water (see Figure 12) [134,135]. The homogenous distribution of alloying elements is not only important for creating these interfaces but also to enhance pitting corrosion. As was demonstrated in the case of Al-Sn-Zn alloys, the good mixing of Zn achieved through HPT-processing can increase the hydrogen generation rate and yield by accelerating the corrosion of the material [136]. Photocatalytic water splitting by $\mathrm{TiO}_{2}$ is another method for hydrogen generation. During the HPT process of the oxide powder, a $\mathrm{TiO}_{2}$ (anatase) $\rightarrow$ $\mathrm{TiO}_{2}$-II (orthorhombic) phase transformation takes place, resulting in a narrower bandgap, which improves the hydrogen generation rate under visible light $[137,138]$.

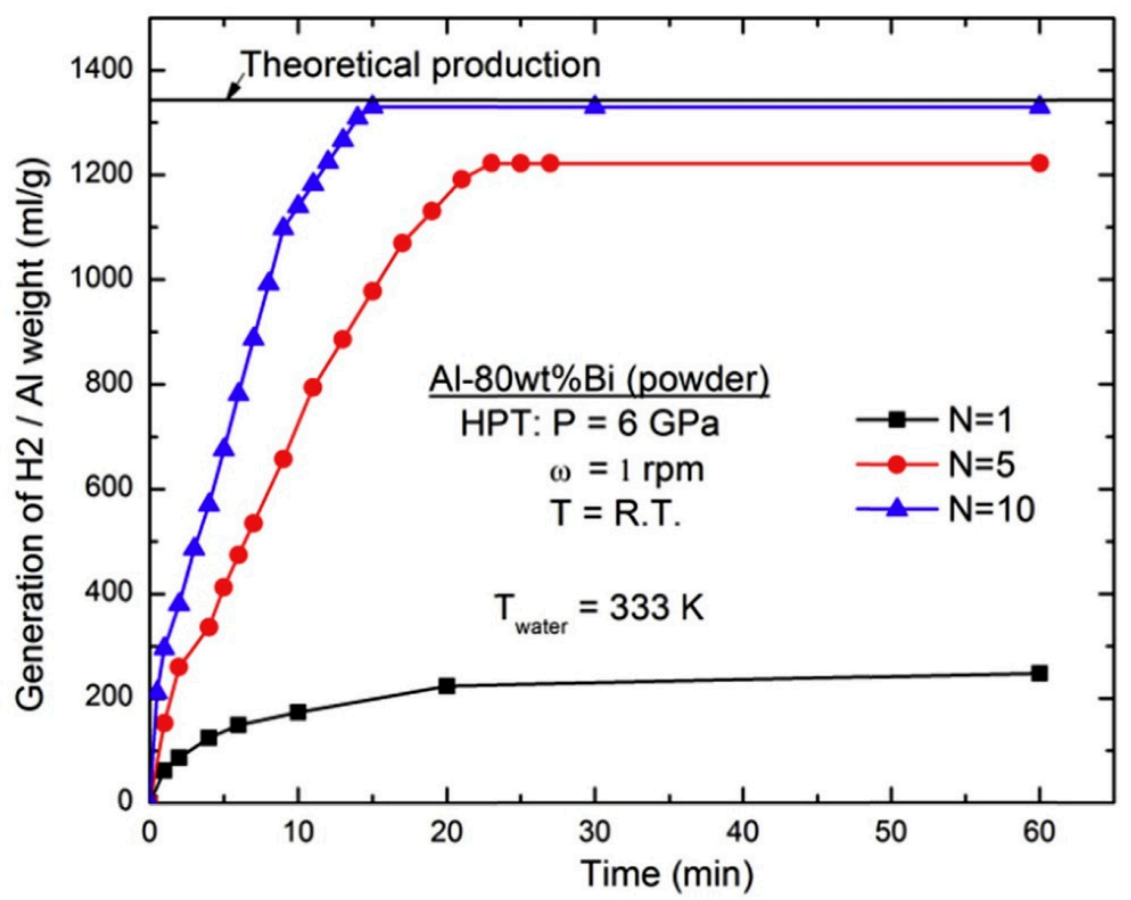

Figure 12. Hydrogen generation against time for Al-80 wt.\% Bi alloy processed by HPT with different number of revolutions $(\mathrm{N}=1,5,10)[135]$.

\section{Conclusions}

In a sustainable energy future, hydrogen will enjoy a solid and pronounced position, since it exhibits the largest energy density. However, one of the key challenges in the hydrogen economy, the efficient and safe way of energy storage is yet to be solved. In spite of the wide range of materials capable of storing hydrogen, kinetic, thermodynamic, or reversibility issues hamper the application of these materials. In recent years considerable efforts have been directed towards the investigation of different methods to improve the hydrogen storage properties. As a result, numerous catalysts, new hydrogen storage compounds, and processing techniques have been developed.

In the present paper, we reviewed the latest assessments of the on-going basic research on the hydrogen storage performance of a broad group of non-equilibrium materials processed by high-pressure torsion. In general, the torsion procedure is used to enhance the absorption/desorption kinetics by means of grain refinement, the introduction of highangle grain boundaries, and texture as was demonstrated in the case of various crystalline Mg-based materials. The severe shear strain can also affect the storage properties of 
amorphous alloys, notably lowering the hydrogen sorption temperature. Other hydrogen storing materials, like different Ti-based alloys, can exhibit improved activation properties and air resistance due to the high-pressure torsion process. HPT can even enhance the hydrogen generation behavior (hydrolysis and photocatalytic water splitting) of different systems. Aside from improving the properties of materials, new compounds and metastable phases can also be manufactured via high-pressure torsion.

Nevertheless, further, improvement is still required prior to wide-spread applications, which should incorporate additional research and development. The main goal in the next years is to take steps towards the up-scaling and commercialization of these systems. The proper combination of different deformation techniques can be used not only to fine tune the microstructure of certain materials for better $\mathrm{H}$-storage performance but also enables the manufacture of larger material quantities.

Author Contributions: Á.R., M.G.; writing—original draft preparation, Á.R.; supervision. All authors have read and agreed to the published version of the manuscript.

Funding: This work was completed in the ELTE Institutional Excellence Program (TKP2020-IKA-05) financed by the Hungarian Ministry of Human Capacities.

Conflicts of Interest: The authors declare no conflict of interest. The funders had no role in the design of the study; in the collection, analyses, or interpretation of data; in the writing of the manuscript, or in the decision to publish the results.

\section{References}

1. Abe, J.O.; Popoola, A.P.I.; Ajenifuja, E.; Popoola, O.M. Hydrogen Energy, Economy and Storage: Review and Recommendation. Int. J. Hydrogen Energy 2019, 44, 15072-15086. [CrossRef]

2. Jain, I.P. Hydrogen the Fuel for 21st Century. Int. J. Hydrogen Energy 2009, 34, 7368-7378. [CrossRef]

3. International Energy Agency. Key World Energy Statistics 2020. Available online: https://www.iea.org/reports/key-worldenergy-statistics-2020 (accessed on 5 December 2020).

4. Abdalla, A.M.; Hossain, S.; Nisfindy, O.B.; Azad, A.T.; Dawood, M.; Azad, A.K. Hydrogen Production, Storage, Transportation and Key Challenges with Applications: A Review. Energy Convers. Manag. 2018, 165, 602-627. [CrossRef]

5. Ren, J.; Musyoka, N.M.; Langmi, H.W.; Mathe, M.; Liao, S. Current Research Trends and Perspectives on Materials-Based Hydrogen Storage Solutions: A Critical Review. Int. J. Hydrogen Energy 2017, 42, 289-311. [CrossRef]

6. Klebanoff, L. Hydrogen Storage Technology: Materials and Application; CRC Press: Boca Raton, FL, USA, 2013; ISBN 978-1-138-19929-3.

7. Sharma, S.; Ghoshal, S.K. Hydrogen the Future Transportation Fuel: From Production to Applications. Renewv. Sustain. Energy Rev. 2015, 43, 1151-1158. [CrossRef]

8. Schlapbach, L.; Züttel, A. Hydrogen-Storage Materials for Mobile Applications. Nature 2001, 414, 353-358. [CrossRef] [PubMed]

9. Rusman, N.A.A.; Dahari, M. A Review on the Current Progress of Metal Hydrides Material for Solid-State Hydrogen Storage Applications. Int. J. Hydrogen Energy 2016, 41, 12108-12126. [CrossRef]

10. Yang, J.; Sudik, A.; Wolverton, C.; Siegel, D.J. High Capacity Hydrogen Storage Materials: Attributes for Automotive Applications and Techniques for Materials Discovery. Chem Soc. Rev. 2010, 39, 656-675. [CrossRef] [PubMed]

11. Niaz, S.; Manzoor, T.; Pandith, A.H. Hydrogen Storage: Materials, Methods and Perspectives. Renew. Sustain. Energy Rev. 2015, 50, 457-469. [CrossRef]

12. US Department of Energy (DOE). Target Explanation Document: Onboard Hydrogen Storage for Light-Duty Fuel Cell Vehicles. Available online: https://www.energy.gov/sites/prod/files/2017/05/f34/fcto_targets_onboard_hydro_storage_explanation.pdf (accessed on 5 December 2020).

13. Wang, H.; Lin, H.J.; Cai, W.T.; Ouyang, L.Z.; Zhu, M. Tuning Kinetics and Thermodynamics of Hydrogen Storage in Light Metal Element Based Systems-A Review of Recent Progress. J. Alloys Compd. 2016, 658, 280-300. [CrossRef]

14. Pasquini, L. Design of Nanomaterials for Hydrogen Storage. Energies 2020, 13, 3503. [CrossRef]

15. Varin, R.A.; Czujko, T.; Wronski, Z.S. Nanomaterials for Solid State Hydrogen Storage; Springer Science: New York, NY, USA, 2009.

16. Crivello, J.-C.; Dam, B.; Denys, R.V.; Dornheim, M.; Grant, D.M.; Huot, J.; Jensen, T.R.; de Jongh, P.; Latroche, M.; Milanese, C.; et al. Review of Magnesium Hydride-Based Materials: Development and Optimisation. Appl. Phys. A 2016, 122, 97. [CrossRef]

17. Khafidz, N.Z.A.K.; Yaakob, Z.; Lim, K.L.; Timmiati, S.N. The Kinetics of Lightweight Solid-State Hydrogen Storage Materials: A Review. Int. J. Hydrogen Energy 2016, 41, 13131-13151. [CrossRef]

18. Aguey-Zinsou, K.-F.; Ares-Fernández, J.-R. Hydrogen in Magnesium: New Perspectives toward Functional Stores. Energy Environ. Sci. 2010, 3, 526-543. [CrossRef]

19. Huot, J.; Cuevas, F.; Deledda, S.; Edalati, K.; Filinchuk, Y.; Grosdidier, T.; Hauback, B.C.; Heere, M.; Jensen, T.R.; Latroche, M.; et al. Mechanochemistry of Metal Hydrides: Recent Advances. Materials 2019, 12, 2778. [CrossRef] 
20. Valiev, R.Z.; Islamgaliev, R.K.; Alexandrov, I.V. Bulk Nanostructured Materials from Severe Plastic Deformation. Prog. Mater. Sci. 2000, 45, 103-189. [CrossRef]

21. Edalati, K.; Akiba, E.; Horita, Z. High-Pressure Torsion for New Hydrogen Storage Materials. Sci. Technol. Adv. Mater. 2018, 19, 185-193. [CrossRef]

22. Leiva, D.R.; Jorge, A.M., Jr.; Ishikawa, T.T.; Botta, W.J. Hydrogen Storage in Mg and Mg-Based Alloys and Composites Processed by Severe Plastic Deformation. Mater. Trans. 2019, 60, 1561-1570. [CrossRef]

23. Edalati, K. Metallurgical Alchemy by Ultra-Severe Plastic Deformation via High-Pressure Torsion Process. Mater. Trans. 2019, 60, 1221-1229. [CrossRef]

24. Edalati, K.; Horita, Z. A Review on High-Pressure Torsion (HPT) from 1935 to 1988. Mater. Sci. Eng. A 2016, 652, 325-352. [CrossRef]

25. Wei, P.T.; Lu, C.; Tieu, K.; Deng, G.Y. A Study of Plastic Deformation Behavior during High Pressure Torsion Process by Crystal Plasticity Finite Element Simulation. IOP Conf. Ser. Mater. Sci. Eng. 2014, 63, 012045. [CrossRef]

26. Zhilyaev, A.; Langdon, T. Using High-Pressure Torsion for Metal Processing: Fundamentals and Applications. Prog. Mater. Sci. 2008, 53, 893-979. [CrossRef]

27. Valiev, R.Z.; Zhilyaev, A.P.; Langdon, T.G. Bulk Nanostructured Materials: Fundamentals and Applications; Wiley-Blackwell: Hoboken, NJ, USA, 2013; ISBN 978-1-118-09540-9.

28. Straumal, B.B.; Mazilkin, A.A.; Baretzky, B.; Schütz, G.; Rabkin, E.; Valiev, R.Z. Accelerated Diffusion and Phase Transformations in Co-Cu Alloys Driven by the Severe Plastic Deformation. Mater. Trans. 2012, 53, 63-71. [CrossRef]

29. Edalati, K.; Horita, Z. High-Pressure Torsion of Pure Metals: Influence of Atomic Bond Parameters and Stacking Fault Energy on Grain Size and Correlation with Hardness. Acta Mater. 2011, 59, 6831-6836. [CrossRef]

30. Boucharat, N.; Rösner, H.; Wilde, G. Nanocrystallization Mechanisms of Al-Rich Glass-Forming Alloys. J. Non Cryst. Solids 2008, 354, 592-596. [CrossRef]

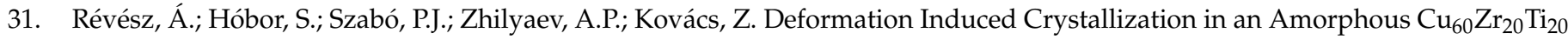
Alloy by High Pressure Torsion. Mater. Sci. Eng. A 2007, 460-461, 459-463. [CrossRef]

32. Révész, Á.; Schafler, E.; Kovács, Z. Structural Anisotropy in a $\mathrm{Zr}_{57} \mathrm{Ti}_{5} \mathrm{Cu}_{20} \mathrm{Al}_{10} \mathrm{Ni}_{8}$ Bulk Metallic Glass Deformed by High Pressure Torsion at Room Temperature. Appl. Phys. Lett. 2008, 92, 011910. [CrossRef]

33. Révész, Á.; Horváth, A.; Ribárik, G.; Schafler, E.; Browne, D.J.; Kovács, Z. Crystallization of $\mathrm{Cu}_{60} \mathrm{Zr}_{20} \mathrm{Ti}_{20}$ Bulk Metallic Glass by High Pressure Torsion. Rev. Adv. Mater. Sci. 2019, 58, 304-312. [CrossRef]

34. Kovács, Z.; Schafler, E.; Révész, Á. Volume Changes in Vitreloy Bulk Metallic Glass during Room Temperature High-Pressure Torsion. J. Mater. Res. 2008, 23, 3409-3414. [CrossRef]

35. Révész, Á.; Kovács, Z. Severe Plastic Deformation of Amorphous Alloys. Mater. Trans. 2019, 60, 1283-1293. [CrossRef]

36. Gunderov, D.; Astanin, V. Influence of HPT Deformation on the Structure and Properties of Amorphous Alloys. Metals 2020, 10, 415. [CrossRef]

37. Edalati, K.; Uehiro, R.; Fujiwara, K.; Ikeda, Y.; Li, H.-W.; Sauvage, X.; Valiev, R.Z.; Akiba, E.; Tanaka, I.; Horita, Z. Ultra-Severe Plastic Deformation: Evolution of Microstructure, Phase Transformation and Hardness in Immiscible Magnesium-Based Systems. Mater. Sci. Eng. A 2017, 701, 158-166. [CrossRef]

38. Bachmaier, A.; Pippan, R. High-Pressure Torsion Deformation Induced Phase Transformations and Formations: New Material Combinations and Advanced Properties. Mater. Trans. 2019, 60, 1256-1269. [CrossRef]

39. Edalati, K.; Hashiguchi, Y.; Pereira, P.H.R.; Horita, Z.; Langdon, T.G. Effect of Temperature Rise on Microstructural Evolution during High-Pressure Torsion. Mater. Sci. Eng. A 2018, 714, 167-171. [CrossRef]

40. Edalati, K.; Miresmaeili, R.; Horita, Z.; Kanayama, H.; Pippan, R. Significance of Temperature Increase in Processing by High-Pressure Torsion. Mater. Sci. Eng. A 2011, 528, 7301-7305. [CrossRef]

41. Henits, P.; Révész, Á.; Kovács, Z. Free Volume Simulation for Severe Plastic Deformation of Metallic Glasses. Mech. Mater. 2012, 50, 81-87. [CrossRef]

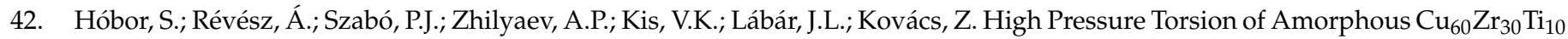
Alloy. J. Appl. Phys. 2008, 104, 033525. [CrossRef]

43. Hóbor, S.; Kovács, Z.; Révész, Á. Macroscopic Thermoplastic Model Applied to the High Pressure Torsion of Metallic Glasses. J. Appl. Phys. 2009, 106, 023531. [CrossRef]

44. Edalati, K.; Horita, Z. Continuous High-Pressure Torsion. J. Mater. Sci. 2010, 45, 4578-4582. [CrossRef]

45. Edalati, K.; Horita, Z. Scaling-Up of High Pressure Torsion Using Ring Shape. Mater. Trans. 2009, 50, 92-95. [CrossRef]

46. Song, Y.; Yoon, E.Y.; Lee, D.J.; Lee, J.H.; Kim, H.S. Mechanical Properties of Copper after Compression Stage of High-Pressure Torsion. Mater. Sci. Eng. A 2011, 528, 4840-4844. [CrossRef]

47. Grau-Crespo, R.; Smith, K.C.; Fisher, T.S.; de Leeuw, N.H.; Waghmare, U.V. Thermodynamics of Hydrogen Vacancies in $\mathrm{MgH}_{2}$ from First-Principles Calculations and Grand-Canonical Statistical Mechanics. Phys. Rev. B 2009, 80, 174117. [CrossRef]

48. Züttel, A. Materials for Hydrogen Storage. Mater. Today 2003, 6, 24-33. [CrossRef]

49. Zaluski, L.; Zaluska, A.; Tessier, P.; Stroem-Olsen, J.O.; Schulz, R. Nanocrystalline Hydrogen Absorbing Alloys. Mater. Sci. Forum 1996, 225-227, 853-858. [CrossRef]

50. Oelerich, W.; Klassen, T.; Bormann, R. Metal Oxides as Catalysts for Improved Hydrogen Sorption in Nanocrystalline Mg-Based Materials. J. Alloys Compd. 2001, 315, 237-242. [CrossRef] 
51. Fátay, D.; Révész, Á.; Spassov, T. Particle Size and Catalytic Effect on the Dehydriding of MgH 2 . J. Alloys Compd. 2005, 399, 237-241. [CrossRef]

52. Fátay, D.; Spassov, T.; Delchev, P.; Ribárik, G.; Révész, A. Microstructural Development in Nanocrystalline $\mathrm{MgH}_{2}$ during H-Absorption/Desorption Cycling. Int. J. Hydrogen Energy 2007, 32, 2914-2919. [CrossRef]

53. Révész, Â.; Fátay, D. Microstructural Evolution of Ball-Milled $\mathrm{MgH}_{2}$ during a Complete Dehydrogenation-Hydrogenation Cycle. J. Power Sources 2010, 195, 6997-7002. [CrossRef]

54. Paidar, V. Magnesium Hydrides and Their Phase Transitions. Int. J. Hydrogen Energy 2016, 41, 9769-9773. [CrossRef]

55. Zhou, S.; Zhang, Q.; Chen, H.; Zang, X.; Zhou, X.; Wang, R.; Jiang, X.; Yang, B.; Jiang, R. Crystalline Structure, Energy Calculation and Dehydriding Thermodynamics of Magnesium Hydride from Reactive Milling. Int. J. Hydrogen Energy 2015, 40, 11484-11490. [CrossRef]

56. Leiva, D.R.; Jorge, A.M.; Ishikawa, T.T.; Huot, J.; Fruchart, D.; Miraglia, S.; Kiminami, C.S.; Botta, W.J. Nanoscale Grain Refinement and $\mathrm{H}$-Sorption Properties of $\mathrm{MgH}_{2}$ Processed by High-Pressure Torsion and Other Mechanical Routes. Adv. Eng. Mater. 2010, 12, 786-792. [CrossRef]

57. Edalati, K.; Kitabayashi, K.; Ikeda, Y.; Matsuda, J.; Li, H.-W.; Tanaka, I.; Akiba, E.; Horita, Z. Bulk Nanocrystalline Gamma Magnesium Hydride with Low Dehydrogenation Temperature Stabilized by Plastic Straining via High-Pressure Torsion. Scr. Mater. 2018, 157, 54-57. [CrossRef]

58. Panda, S.; Fundenberger, J.-J.; Zhao, Y.; Zou, J.; Toth, L.S.; Grosdidier, T. Effect of Initial Powder Type on the Hydrogen Storage Properties of High-Pressure Torsion Consolidated Mg. Int. J. Hydrogen Energy 2017, 42, 22438-22448. [CrossRef]

59. Edalati, K.; Yamamoto, A.; Horita, Z.; Ishihara, T. High-Pressure Torsion of Pure Magnesium: Evolution of Mechanical Properties, Microstructures and Hydrogen Storage Capacity with Equivalent Strain. Scr. Mater. 2011, 64, 880-883. [CrossRef]

60. Révész, Á.; Gajdics, M. Correlation between Microstructure and Hydrogen Storage Properties of Nanocrystalline Magnesium Subjected to High-Pressure Torsion. Mater. Sci. Forum 2017, 885, 67-73. [CrossRef]

61. Grill, A.; Horky, J.; Panigrahi, A.; Krexner, G.; Zehetbauer, M. Long-Term Hydrogen Storage in Mg and ZK60 after Severe Plastic Deformation. Int. J. Hydrogen Energy 2015, 40, 17144-17152. [CrossRef]

62. Zeng, K.; Klassen, T.; Oelerich, W.; Bormann, R. Thermodynamic Analysis of the Hydriding Process of Mg-Ni Alloys. J. Alloys Compd. 1999, 283, 213-224. [CrossRef]

63. Liang, G.; Boily, S.; Huot, J.; Van Neste, A.; Schulz, R. Mechanical Alloying and Hydrogen Absorption Properties of the Mg-Ni System. J. Alloys Compd. 1998, 267, 302-306. [CrossRef]

64. Zaluska, A.; Zaluski, L.; Ström-Olsen, J.O. Structure, Catalysis and Atomic Reactions on the Nano-Scale: A Systematic Approach to Metal Hydrides for Hydrogen Storage. Appl. Phys. A 2001, 72, 157-165. [CrossRef]

65. Massalski, T.B.; Murray, J.L.; Bennett, L.H.; Baker, H. Binary Alloy Phase Diagrams; American Society for Metals: Materials Park, OH, USA, 1986; ISBN 978-0-87170-261-6.

66. Reilly, J.J., Jr.; Wishwall, R.H., Jr. Reaction of Hydrogen with Alloys of Magnesium and Nickel and the Formation of $\mathrm{Mg}_{2} \mathrm{NiH}_{4}$. Inorg. Chem. 1968, 7, 2254-2256. [CrossRef]

67. Simchi, H.; Kaflou, A.; Simchi, A. Synergetic Effect of $\mathrm{Ni}$ and $\mathrm{Nb}_{2} \mathrm{O}_{5}$ on Dehydrogenation Properties of $\mathrm{Nanostructured} \mathrm{MgH}_{2}$ Synthesized by High-Energy Mechanical Alloying. Int. J. Hydrogen Energy 2009, 34, 7724-7730. [CrossRef]

68. Xie, L.; Li, J.; Zhang, T.; Kou, H. Understanding the Dehydrogenation Process of $\mathrm{MgH}_{2}$ from the Recombination of Hydrogen Atoms. Int. J. Hydrogen Energy 2016, 41, 5716-5724. [CrossRef]

69. Urretavizcaya, G.; García, G.; Serafini, D.; Meyer, G. Mg-Ni Alloys For Hydrogen Storage Obtained By Ball Milling. Lat. Am. Appl. Res. 2002, 32, 289-294.

70. Varin, R.A.; Czujko, T.; Mizera, J. Microstructural Evolution during Controlled Ball Milling of $\left(\mathrm{Mg}_{2} \mathrm{Ni}+\mathrm{MgNi}_{2}\right)$ Intermetallic Alloy. J. Alloys Compd. 2003, 350, 332-339. [CrossRef]

71. Révész, Á.; Gajdics, M.; Spassov, T. Microstructural Evolution of Ball-Milled Mg-Ni Powder during Hydrogen Sorption. Int. J. Hydrogen Energy 2013, 38, 8342-8349. [CrossRef]

72. Orimo, S.; Ikeda, K.; Fujii, H.; Fujikawa, Y.; Kitano, Y.; Yamamoto, K. Structural and Hydriding Properties of the Mg-Ni-H System with Nano- and/or Amorphous Structures. Acta Mater. 1997, 45, 2271-2278. [CrossRef]

73. Kusadome, Y.; Ikeda, K.; Nakamori, Y.; Orimo, S.; Horita, Z. Hydrogen Storage Capability of MgNi 2 Processed by High Pressure Torsion. Scr. Mater. 2007, 57, 751-753. [CrossRef]

74. Révész, Á.; Kánya, Z.; Verebélyi, T.; Szabó, P.J.; Zhilyaev, A.P.; Spassov, T. The Effect of High-Pressure Torsion on the Microstructure and Hydrogen Absorption Kinetics of Ball-Milled $\mathrm{Mg}_{70} \mathrm{Ni}_{30}$. J. Alloys Compd. 2010, 504, 83-88. [CrossRef]

75. Hongo, T.; Edalati, K.; Arita, M.; Matsuda, J.; Akiba, E.; Horita, Z. Significance of Grain Boundaries and Stacking Faults on Hydrogen Storage Properties of $\mathrm{Mg}_{2} \mathrm{Ni}$ Intermetallics Processed by High-Pressure Torsion. Acta Mater. 2015, 92, 46-54. [CrossRef]

76. Grosdidier, T.; Fundenberger, J.J.; Zou, J.X.; Pan, Y.C.; Zeng, X.Q. Nanostructured Mg Based Hydrogen Storage Bulk Materials Prepared by High Pressure Torsion Consolidation of Arc Plasma Evaporated Ultrafine Powders. Int. J. Hydrogen Energy 2015, 40, 16985-16991. [CrossRef]

77. Gajdics, M.; Calizzi, M.; Pasquini, L.; Schafler, E.; Révész, Á. Characterization of a Nanocrystalline Mg-Ni Alloy Processed by High-Pressure Torsion during Hydrogenation and Dehydrogenation. Int. J. Hydrogen Energy 2016, 41, 9803-9809. [CrossRef]

78. Révész, Á.; Gajdics, M.; Schafler, E.; Calizzi, M.; Pasquini, L. Dehydrogenation-Hydrogenation Characteristics of Nanocrystalline $\mathrm{Mg}_{2} \mathrm{Ni}$ Powders Compacted by High-Pressure Torsion. J. Alloys Compd. 2017, 702, 84-91. [CrossRef] 
79. Dębski, A.; Terlicka, S.; Gąsior, W.; Gierlotka, W.; Pęska, M.; Polański, M. Thermodynamic Properties of Mg-Pd Liquid Alloys. J. Mol. Liq. 2020, 317, 114024. [CrossRef]

80. Edalati, K.; Emami, H.; Staykov, A.; Smith, D.J.; Akiba, E.; Horita, Z. Formation of Metastable Phases in Magnesium-Titanium System by High-Pressure Torsion and Their Hydrogen Storage Performance. Acta Mater. 2015, 99, 150-156. [CrossRef]

81. Edalati, K.; Emami, H.; Ikeda, Y.; Iwaoka, H.; Tanaka, I.; Akiba, E.; Horita, Z. New Nanostructured Phases with Reversible Hydrogen Storage Capability in Immiscible Magnesium-Zirconium System Produced by High-Pressure Torsion. Acta Mater. 2016, 108, 293-303. [CrossRef]

82. Kitabayashi, K.; Edalati, K.; Li, H.; Akiba, E.; Horita, Z. Phase Transformations in $\mathrm{MgH}_{2}-\mathrm{TiH}_{2}$ Hydrogen Storage System by High-Pressure Torsion Process. Adv. Eng. Mater. 2020, 22, 1900027. [CrossRef]

83. Edalati, K.; Uehiro, R.; Ikeda, Y.; Li, H.-W.; Emami, H.; Filinchuk, Y.; Arita, M.; Sauvage, X.; Tanaka, I.; Akiba, E.; et al. Design and Synthesis of a Magnesium Alloy for Room Temperature Hydrogen Storage. Acta Mater. 2018, 149, 88-96. [CrossRef]

84. López Gómez, E.I.; Edalati, K.; Coimbrão, D.D.; Antiqueira, F.J.; Zepon, G.; Cubero-Sesin, J.M.; Botta, W.J. FCC Phase Formation in Immiscible Mg-Hf (Magnesium-Hafnium) System by High-Pressure Torsion. AIP Adv. 2020, 10, 055222. [CrossRef]

85. De Marco, M.O.; Li, Y.; Li, H.-W.; Edalati, K.; Floriano, R. Mechanical Synthesis and Hydrogen Storage Characterization of MgVCr and MgVTiCrFe High-Entropy Alloy. Adv. Eng. Mater. 2020, 22, 1901079. [CrossRef]

86. Aminorroaya, S.; Liu, H.K.; Cho, Y.; Dahle, A. Microstructure and Activation Characteristics of Mg-Ni Alloy Modified by Multi-Walled Carbon Nanotubes. Int. J. Hydrogen Energy 2010, 35, 4144-4153. [CrossRef]

87. Hou, X.; Hu, R.; Zhang, T.; Kou, H.; Li, J. Hydrogenation Thermodynamics of Melt-Spun Magnesium Rich Mg-Ni Nanocrystalline Alloys with the Addition of Multiwalled Carbon Nanotubes and $\mathrm{TiF}_{3}$. J. Power Sources 2016, 306, 437-447. [CrossRef]

88. Chen, B.-H.; Kuo, C.-H.; Ku, J.-R.; Yan, P.-S.; Huang, C.-J.; Jeng, M.-S.; Tsau, F.-H. Highly Improved with Hydrogen Storage Capacity and Fast Kinetics in Mg-Based Nanocomposites by CNTs. J. Alloys Compd. 2013, 568, 78-83. [CrossRef]

89. Su, W.; Zhu, Y.; Zhang, J.; Liu, Y.; Yang, Y.; Mao, Q.; Li, L. Effect of Multi-Wall Carbon Nanotubes Supported Nano-Nickel and $\mathrm{TiF}_{3}$ Addition on Hydrogen Storage Properties of Magnesium Hydride. J. Alloys Compd. 2016, 669, 8-18. [CrossRef]

90. Shahi, R.R.; Bhatnagar, A.; Pandey, S.K.; Dixit, V.; Srivastava, O.N. Effects of Ti-Based Catalysts and Synergistic Effect of SWCNTs-TiF 3 on Hydrogen Uptake and Release from $\mathrm{MgH}_{2}$. Int. J. Hydrogen Energy 2014, 39, 14255-14261. [CrossRef]

91. Amirkhiz, B.S.; Danaie, M.; Barnes, M.; Simard, B.; Mitlin, D. Hydrogen Sorption Cycling Kinetic Stability and Microstructure of Single-Walled Carbon Nanotube (SWCNT) Magnesium Hydride $\left(\mathrm{MgH}_{2}\right)$ Nanocomposites. J. Phys. Chem. C 2010, 114, $3265-3275$. [CrossRef]

92. Verón, M.G.; Troiani, H.; Gennari, F.C. Synergetic Effect of Co and Carbon Nanotubes on $\mathrm{MgH}_{2}$ Sorption Properties. Carbon 2011, 49, 2413-2423. [CrossRef]

93. Chuang, Y.-S.; Hwang, S.-J. Synthesis and Hydrogen Absorption/Desorption Properties of $\mathrm{Mg}_{-}-\mathrm{Nb}_{2} \mathrm{O}_{5}-\mathrm{SWCNT}_{\mathrm{MWCNT}}$ Nanocomposite Prepared by Reactive Milling. J. Alloys Compd. 2016, 656, 835-842. [CrossRef]

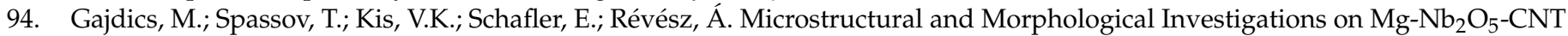
Nanocomposites Processed by High-Pressure Torsion for Hydrogen Storage Applications. Int. J. Hydrogen Energy 2020, 45, 7917-7928. [CrossRef]

95. Révész, Á.; Spassov, T.; Kis, V.K.; Schafler, E.; Gajdics, M. The Influence of Preparation Conditions on the Hydrogen Sorption of $\mathrm{Mg}-\mathrm{Nb}_{2} \mathrm{O}_{5}-\mathrm{CNT}$ Produced by Ball Milling and Subsequent High-Pressure Torsion. J. Nanosci. Nanotechnol. 2020, 20, 4587-4590. [CrossRef]

96. Gajdics, M.; Spassov, T.; Kis, V.K.; Béke, F.; Novák, Z.; Schafler, E.; Révész, Á. Microstructural Investigation of Nanocrystalline Hydrogen-Storing Mg-Titanate Nanotube Composites Processed by High-Pressure Torsion. Energies 2020, 13, 563. [CrossRef]

97. Hara, M.; Morozumi, S.; Watanabe, K. Effect of a Magnesium Depletion on the Mg-Ni-Y Alloy Hydrogen Absorption Properties. J. Alloys Compd. 2006, 414, 207-214. [CrossRef]

98. Yang, T.; Wang, P.; Li, Q.; Xia, C.; Yin, F.; Liang, C.; Zhang, Y. Hydrogen Absorption and Desorption Behavior of Ni Catalyzed Mg-Y-C-Ni Nanocomposites. Energy 2018, 165, 709-719. [CrossRef]

99. Zhang, Y.; Zhao, D.; Li, B.; Ren, H.; Guo, S.; Wang, X. Electrochemical Hydrogen Storage Characteristics of Nanocrystalline $\mathrm{Mg}_{20} \mathrm{Ni}_{10-\mathrm{x}} \mathrm{Co}_{\mathrm{x}}(\mathrm{X}=0-4)$ Alloys Prepared by Melt-Spinning. J. Alloys Compd. 2010, 491, 589-594. [CrossRef]

100. Si, T.Z.; Liu, Y.F.; Zhang, Q.A. Hydrogen Storage Properties of the Supersaturated $\mathrm{Mg}_{12}$ YNi Solid Solution. J. Alloys Compd. 2010, 507, 489-493. [CrossRef]

101. Kalinichenka, S.; Röntzsch, L.; Baehtz, C.; Kieback, B. Hydrogen Desorption Kinetics of Melt-Spun and Hydrogenated Mg ${ }_{90} \mathrm{Ni}_{10}$ and $\mathrm{Mg}_{80} \mathrm{Ni}_{10} \mathrm{Y}_{10}$ Using in Situ Synchrotron, X-Ray Diffraction and Thermogravimetry. J. Alloys Compd. 2010, 496, 608-613. [CrossRef]

102. Spassov, T.; Köster, U. Thermal Stability and Hydriding Properties of Nanocrystalline Melt-Spun $\mathrm{Mg}_{63} \mathrm{Ni}_{30} \mathrm{Y}_{7} \mathrm{Alloy}$ J. Alloys Compd. 1998, 279, 279-286. [CrossRef]

103. Chen, H.; Wang, Z.; Zhou, H.; Ni, C.; Deng, J.; Yao, Q. Hydrogen Storage Properties and Thermal Stability of Amorphous $\mathrm{Mg}_{70}\left(\mathrm{RE}_{25} \mathrm{Ni}_{75}\right)_{30}$ Alloys. J. Alloys Compd. 2013, 563, 1-5. [CrossRef]

104. Zhang, Q.A.; Jiang, C.J.; Liu, D.D. Comparative Investigations on the Hydrogenation Characteristics and Hydrogen Storage Kinetics of Melt-Spun $\mathrm{Mg}_{10} \mathrm{NiR}(\mathrm{R}=\mathrm{La}, \mathrm{Nd}$ and Sm) Alloys. Int. J. Hydrogen Energy 2012, 37, 10709-10714. [CrossRef] 
105. Lin, H.-J.; He, M.; Pan, S.-P.; Gu, L.; Li, H.-W.; Wang, H.; Ouyang, L.-Z.; Liu, J.-W.; Ge, T.-P.; Wang, D.-P.; et al. Towards Easily Tunable Hydrogen Storage via a Hydrogen-Induced Glass-to-Glass Transition in Mg-Based Metallic Glasses. Acta Mater. 2016, 120, 68-74. [CrossRef]

106. Spassov, T.; Köster, U. Hydrogenation of Amorphous and Nanocrystalline Mg-Based Alloys. J. Alloys Compd. 1999, 287, 243-250. [CrossRef]

107. Kalinichenka, S.; Röntzsch, L.; Kieback, B. Structural and Hydrogen Storage Properties of Melt-Spun Mg-Ni-Y Alloys. Int. J. Hydrogen Energy 2009, 34, 7749-7755. [CrossRef]

108. Wu, Y.; Solberg, J.K.; Yartys, V.A. The Effect of Solidification Rate on Microstructural Evolution of a Melt-Spun Mg-20Ni-8Mm Hydrogen Storage Alloy. J. Alloys Compd. 2007, 446-447, 178-182. [CrossRef]

109. Zhang, Y.; Li, B.; Ren, H.; Ding, X.; Liu, X.; Chen, L. An Investigation on Hydrogen Storage Kinetics of Nanocrystalline and Amorphous $\mathrm{Mg}_{2} \mathrm{Ni}_{1-\mathrm{x}} \mathrm{Co}_{\mathrm{x}}(\mathrm{X}=0$-0.4) Alloy Prepared by Melt Spinning. J. Alloys Compd. 2011, 509, 2808-2814. [CrossRef]

110. Zhang, Y.; Li, B.; Ren, H.; Guo, S.; Zhao, D.; Wang, X. Hydrogenation and Dehydrogenation Behaviours of Nanocrystalline $\mathrm{Mg}_{20} \mathrm{Ni}_{10-\mathrm{x}} \mathrm{Cu}_{\mathrm{x}}(\mathrm{X}=\mathrm{0}-4)$ Alloys Prepared by Melt Spinning. Int. J. Hydrogen Energy 2010, 35, 2040-2047. [CrossRef]

111. Yang, T.; Wang, P.; Xia, C.; Li, Q.; Liang, C.; Zhang, Y. Characterization of Microstructure, Hydrogen Storage Kinetics and Thermodynamics of a Melt-Spun $\mathrm{Mg}_{86} \mathrm{Y}_{10} \mathrm{Ni}_{4}$ Alloy. Int. J. Hydrogen Energy 2019, 44, 6728-6737. [CrossRef]

112. Wu, Y.; Lototskyy, M.V.; Solberg, J.K.; Yartys, V.A. Effect of Microstructure on the Phase Composition and Hydrogen AbsorptionDesorption Behaviour of Melt-Spun Mg-20Ni-8Mm Alloys. Int. J. Hydrogen Energy 2012, 37, 1495-1508. [CrossRef]

113. Denys, R.V.; Poletaev, A.A.; Maehlen, J.P.; Solberg, J.K.; Tarasov, B.P.; Yartys, V.A. Nanostructured Rapidly Solidified LaMg ${ }_{11}$ Ni Alloy. II. In Situ Synchrotron X-Ray Diffraction Studies of Hydrogen Absorption-Desorption Behaviours. Int. J. Hydrogen Energy 2012, 37, 5710-5722. [CrossRef]

114. Révész, Á.; Kis-Tóth, Á.; Varga, L.K.; Lábár, J.L.; Spassov, T. High Glass Forming Ability Correlated with Microstructure and Hydrogen Storage Properties of a Mg-Cu-Ag-Y Glass. Int. J. Hydrogen Energy 2014, 39, 9230-9240. [CrossRef]

115. Xu, C.; Lin, H.-J.; Edalati, K.; Li, W.; Li, L.; Zhu, Y. Superior Hydrogenation Properties in a $\mathrm{Mg}_{65} \mathrm{Ce}_{10} \mathrm{Ni}_{20} \mathrm{Cu}_{5} \mathrm{Nanoglass}$ Processed by Melt-Spinning Followed by High-Pressure Torsion. Scr. Mater. 2018, 152, 137-140. [CrossRef]

116. Révész, Â.; Kis-Tóth, Á.; Varga, L.K.; Schafler, E.; Bakonyi, I.; Spassov, T. Hydrogen Storage of Melt-Spun Amorphous $\mathrm{Mg}_{65} \mathrm{Ni}_{20} \mathrm{Cu}_{5} \mathrm{Y}_{10}$ Alloy Deformed by High-Pressure Torsion. Int. J. Hydrogen Energy 2012, 37, 5769-5776. [CrossRef]

117. Révész, Á.; Kis-Tóth, Á.; Szommer, P.; Spassov, T. Hydrogen Storage, Microstructure and Mechanical Properties of Strained $\mathrm{Mg}_{65} \mathrm{Ni}_{20} \mathrm{Cu}_{5} \mathrm{Y}_{10}$ Metallic Glass. Mater. Sci. Forum 2013, 729, 74-79. [CrossRef]

118. Spaepen, F. A Microscopic Mechanism for Steady State Inhomogeneous Flow in Metallic Glasses. Acta Metall. 1977, 25, 407-415. [CrossRef]

119. Reilly, J.J.; Wiswall, R.H. Formation and Properties of Iron Titanium Hydride. Inorg. Chem. 1974, 13, 218-222. [CrossRef]

120. Edalati, K.; Matsuda, J.; Iwaoka, H.; Toh, S.; Akiba, E.; Horita, Z. High-Pressure Torsion of TiFe Intermetallics for Activation of Hydrogen Storage at Room Temperature with Heterogeneous Nanostructure. Int. J. Hydrogen Energy 2013, 38, $4622-4627$. [CrossRef]

121. Edalati, K.; Matsuda, J.; Arita, M.; Daio, T.; Akiba, E.; Horita, Z. Mechanism of Activation of TiFe Intermetallics for Hydrogen Storage by Severe Plastic Deformation Using High-Pressure Torsion. Appl. Phys. Lett. 2013, 103, 143902. [CrossRef]

122. Edalati, K.; Matsuda, J.; Yanagida, A.; Akiba, E.; Horita, Z. Activation of TiFe for Hydrogen Storage by Plastic Deformation Using Groove Rolling and High-Pressure Torsion: Similarities and Differences. Int. J. Hydrogen Energy 2014, 39, 15589-15594. [CrossRef]

123. Lv, P.; Liu, Z.; Dixit, V. Improved Hydrogen Storage Properties of TiFe Alloy by Doping (Zr+2V) Additive and Using Mechanical Deformation. Int. J. Hydrogen Energy 2019, 44, 27843-27852. [CrossRef]

124. Emami, H.; Edalati, K.; Matsuda, J.; Akiba, E.; Horita, Z. Hydrogen Storage Performance of TiFe after Processing by Ball Milling. Acta Mater. 2015, 88, 190-195. [CrossRef]

125. Edalati, K.; Matsuo, M.; Emami, H.; Itano, S.; Alhamidi, A.; Staykov, A.; Smith, D.J.; Orimo, S.; Akiba, E.; Horita, Z. Impact of Severe Plastic Deformation on Microstructure and Hydrogen Storage of Titanium-Iron-Manganese Intermetallics. Scr. Mater. 2016, 124, 108-111. [CrossRef]

126. Gómez, E.I.L.; Edalati, K.; Antiqueira, F.J.; Coimbrão, D.D.; Zepon, G.; Leiva, D.R.; Ishikawa, T.T.; Cubero-Sesin, J.M.; Botta, W.J. Synthesis of Nanostructured TiFe Hydrogen Storage Material by Mechanical Alloying via High-Pressure Torsion. Adv. Eng. Mater. 2020, 22, 2000011. [CrossRef]

127. Edalati, K.; Shao, H.; Emami, H.; Iwaoka, H.; Akiba, E.; Horita, Z. Activation of Titanium-Vanadium Alloy for Hydrogen Storage by Introduction of Nanograins and Edge Dislocations Using High-Pressure Torsion. Int. J. Hydrogen Energy 2016, 41, 8917-8924. [CrossRef]

128. Edalati, K.; Novelli, M.; Itano, S.; Li, H.-W.; Akiba, E.; Horita, Z.; Grosdidier, T. Effect of Gradient-Structure versus Uniform Nanostructure on Hydrogen Storage of Ti-V-Cr Alloys: Investigation Using Ultrasonic SMAT and HPT Processes. J. Alloys Compd. 2018, 737, 337-346. [CrossRef]

129. Novelli, M.; Edalati, K.; Itano, S.; Li, H.-W.; Akiba, E.; Horita, Z.; Grosdidier, T. Microstructural Details of Hydrogen Diffusion and Storage in Ti-V-Cr Alloys Activated through Surface and Bulk Severe Plastic Deformation. Int. J. Hydrogen Energy 2020, 45, 5326-5336. [CrossRef]

130. Iwaoka, H.; Horita, Z. Hydrogen Behavior in Ultrafine-Grained Palladium Processed by High-Pressure Torsion. Int. J. Hydrogen Energy 2013, 38, 14879-14886. [CrossRef] 
131. Iwaoka, H.; Arita, M.; Horita, Z. Hydrogen Diffusion in Ultrafine-Grained Palladium: Roles of Dislocations and Grain Boundaries. Acta Mater. 2016, 107, 168-177. [CrossRef]

132. Krystian, M.; Setman, D.; Mingler, B.; Krexner, G.; Zehetbauer, M.J. Formation of Superabundant Vacancies in Nano-Pd-H Generated by High-Pressure Torsion. Scr. Mater. 2010, 62, 49-52. [CrossRef]

133. Hongo, T.; Edalati, K.; Iwaoka, H.; Arita, M.; Matsuda, J.; Akiba, E.; Horita, Z. High-Pressure Torsion of Palladium: HydrogenInduced Softening and Plasticity in Ultrafine Grains and Hydrogen-Induced Hardening and Embrittlement in Coarse Grains. Mater. Sci. Eng. A 2014, 618, 1-8. [CrossRef]

134. Zhang, F.; Yonemoto, R.; Arita, M.; Horita, Z. Hydrogen Generation from Pure Water Using Al-Sn Powders Consolidated through High-Pressure Torsion. J. Mater. Res. 2016, 31, 775-782. [CrossRef]

135. Zhang, F.; Edalati, K.; Arita, M.; Horita, Z. Fast Hydrolysis and Hydrogen Generation on Al-Bi Alloys and Al-Bi-C Composites Synthesized by High-Pressure Torsion. Int. J. Hydrogen Energy 2017, 42, 29121-29130. [CrossRef]

136. Zhang, F.; Edalati, K.; Arita, M.; Horita, Z. Hydrolytic Hydrogen Production on Al-Sn-Zn Alloys Processed by High-Pressure Torsion. Materials 2018, 11, 1209. [CrossRef]

137. Razavi-Khosroshahi, H.; Edalati, K.; Hirayama, M.; Emami, H.; Arita, M.; Yamauchi, M.; Hagiwara, H.; Ida, S.; Ishihara, T.; Akiba, E.; et al. Visible-Light-Driven Photocatalytic Hydrogen Generation on Nanosized $\mathrm{TiO}_{2}$-II Stabilized by High-Pressure Torsion. ACS Catal. 2016, 6, 5103-5107. [CrossRef]

138. Edalati, K.; Wang, Q.; Eguchi, H.; Razavi-Khosroshahi, H.; Emami, H.; Yamauchi, M.; Fuji, M.; Horita, Z. Impact of TiÖ-II Phase Stabilized in Anatase Matrix by High-Pressure Torsion on Electrocatalytic Hydrogen Production. Mater. Res. Lett. 2019, 7, 334-339. [CrossRef] 